Article

\title{
Pyrrole and Fused Pyrrole Compounds with Bioactivity against Inflammatory Mediators
}

\author{
Samar Said Fatahala ${ }^{1, *}$, Sherifa Hasabelnaby ${ }^{2,3}$, Ayman Goudah ${ }^{4}$, Ghada I. Mahmoud ${ }^{5}$ \\ and Rania Helmy Abd-El Hameed ${ }^{1}$ \\ 1 Pharmaceutical Organic Chemistry Department, Faculty of Pharmacy, Helwan University, Ain-Helwan, \\ Helwan 11795, Cairo, Egypt; zeiadomar@yahoo.com \\ 2 Pharmaceutical Chemistry Department, Faculty of Pharmacy, Helwan University, Ain-Helwan, \\ Helwan 11795, Cairo, Egypt; sherifajanaa@yahoo.com \\ 3 Department of Chemistry and Biochemistry, Concordia University, 7141 rue Sherbrooke O., Montréal, \\ H4Bm1R6 QC, Canada \\ 4 Department of Pharmacology, Faculty of Veterinary Medicine, Cairo University, Giza/Egypt, Giza 12211, \\ Egypt; aymangouda@yahoo.com \\ 5 Department of Biochemistry, Faculty of Agriculture, Cairo University, Giza/Egypt, Giza 12211, Egypt; \\ ssfathallah@yahoo.com \\ * Correspondence: samarradwan1@yahoo.com; Tel./Fax: +20-2-2554-1601
}

Academic Editor: Diego Muñoz-Torrero

Received: 9 February 2017; Accepted: 11 March 2017; Published: 17 March 2017

\begin{abstract}
A new series of pyrrolopyridines and pyrrolopyridopyrimidines have been synthesized from aminocyanopyrroles. The synthesized compounds have been characterized by FTIR, ${ }^{1} \mathrm{H}-\mathrm{NMR}$ and mass spectroscopy. The final compounds have been screened for in vitro pro-inflammatory cytokine inhibitory and in vivo anti-inflammatory activity. The biological results revealed that among all tested compounds some fused pyrroles, namely the pyrrolopyridines $3 \mathbf{i}$ and $\mathbf{3 l}$, show promising activity. A docking study of the active synthesized molecules confirmed the biological results and revealed a new binding pose in the COX-2 binding site.
\end{abstract}

Keywords: pyrroles; pyrrolopyridines; synthesis; anti-inflammatory assay; cytokine inhibitors; docking study

\section{Introduction}

Non-steroidal anti-inflammatory drugs (NSAIDs) belong to a class of drugs used worldwide for the treatment of pain, fever and inflammatory diseases [1-8]. Recently, use of NSAIDs has been extended [3] to reduce the risk of developing cancer through reduction of inflammation, which is an important risk factor for cancer.

Classical NSAIDs such as aspirin, ibuprofen and diclofenac [3,9-11] represent some of the most widely prescribed NSAIDs to relieve short-term fever, pain and inflammation. Two isoenzymes of cyclo-oxygenase COX, COX-1 (constitutive form) and COX-2 (inducible form), have been identified [4,12,13]. The classical NSAIDs inhibit both isoenzymes and their use is often accompanied by gastrointestinal intolerance [12], due to a decreased production of protective prostaglandin E2 in the stomach. New drugs that selectively inhibit COX-2 exhibit a better gastric tolerance profile $[5,9,11,14-18]$. Among well-known NSAIDs, pyrrole ring derivatives [19] are of remarkable interest [20-23]. Examples are benzo[b]pyrrole derivatives such as indomethacin $\left(\operatorname{Indacin}^{\circledR}\right)$, acemetacin $\left(\right.$ Emflex $\left.^{\circledR}\right)$, and etodolac (Etodine ${ }^{\circledR}$ ) and pyrrole derivatives like tolmetin (Rumatol ${ }^{\circledR}$ ) and ketorolac $\left(\operatorname{Ketolac}^{\circledR}\right)[14,24,25]$. These compounds block prostaglandin synthesis by nonselective inhibition of COX-1 and COX-2 (indomethacin, acemetacin, tolmetin, and ketorolac) or by selective inhibition of COX-2 (etodolac). Rutaecarpine, 
a quinazolinocarboline alkaloid [26,27], has been isolated from some well-known Chinese herbal drugs, namely $\mathrm{Wu}-\mathrm{Chu}-\mathrm{Yu}$, and Shih-Hu. It exhibits a strong anti-inflammatory activity and has shown potent and selective inhibitory activity against COX-2. A series of $N$-pyrrolylcarboxylic acids have been reported to be potent COX-2 inhibitors [28,29]. Also, a group of Merck researchers have reported [30] that L-167307 (pyrrole derivative) showed potent inhibitory activity towards the pro-inflammatory cytokine TNF- $\alpha$. Structures of some of these compounds are shown in Figure 1.

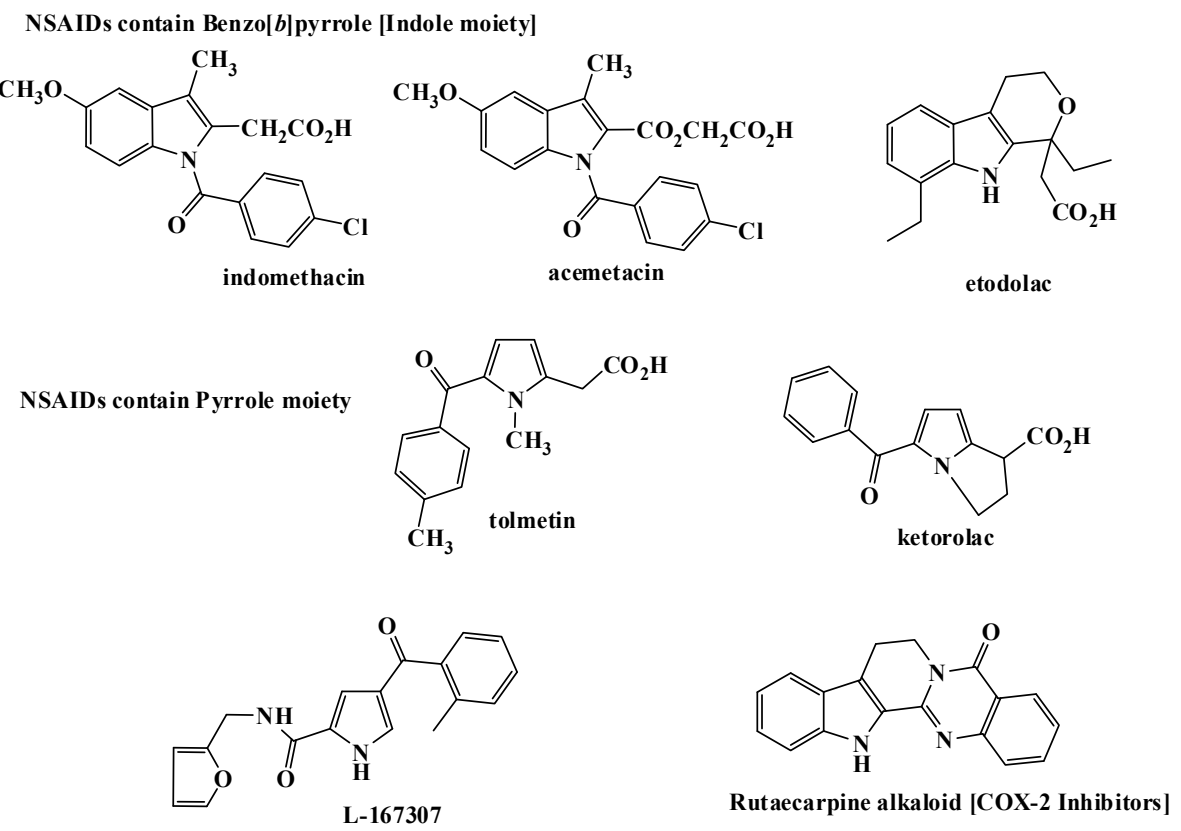

Figure 1. NSAIDS containing pyrroles moiety.

Relatively recent discoveries [31] indicate that long-term use of NSAIDs is associated with numerous risk factors, including ulceration and other adverse effects. Moreover, instead of their ability to improve pain and tenderness, NSAIDs did not prevent disease progression in rheumatoid arthritis [5,32-34], a disease whose pathogenesis has been linked to the presence of pro-inflammatory cytokines, such as interleukin-1 (IL-1 $\beta$ ) or tumor necrosis factor (TNF- $\alpha)$.

Numerous NSAID derivatives [7] have been prepared in order to improve the analgesic/ anti-inflammatory activity, minimize side effects, prolong plasma half-life, increase COX-1/COX-2 selectivity, cytostatic activity and change water solubility or lipophilicity [35-37]. The search for alternative anti-inflammatory drugs with minimal adverse effects is one of the biggest challenges in modern medicinal chemistry. Here we highlight some aspects of the chemistry of some newly synthesized fused pyrrole derivatives and test them for anti-inflammatory activity.

\section{Results}

\subsection{Chemistry}

The synthesis of the target compounds is summarized in Scheme 1. To synthesize compounds 3a-1 and 4a-1, several 2-aminopyrrole-3-carbonitriles 1a-f were prepared by condensing malononitrile with the two intermediates I or II, respectively, in strong basic medium [38-41]. The 2-arylidene malononitriles $\mathbf{2} \mathbf{a}, \mathbf{b}$ were prepared by condensation of malononitrile with the aromatic aldehydes benzaldhyde or anisaldehyde [42-44]. Cyclocondensation of 2-aminopyrrole-3-carbonitriles 1a-f with the 2-arylidene-malononitriles $\mathbf{2} \mathbf{a}, \mathbf{b}$ in refluxing ethanol containing a catalytic amount of piperidine followed by treating [42] the product with crushed ice/dilute $\mathrm{HCl}$, afforded 4-aminopyrrolopyridine carbonitrile derivatives $3 \mathbf{a}-\mathbf{1}$ in yields ranging from $39 \%-94 \%$. The chemical structures of the newly 
synthesized derivatives 3a-1 were established on the basis of analytical and spectral data. Their IR spectra displayed the presence of $\mathrm{NH}_{2}, \mathrm{CN}$, and $\mathrm{C}=\mathrm{N}$ absorption bands in the 3316-3467, 2176-2224 and 1568-1618 $\mathrm{cm}^{-1}$ regions, respectively, as well as the presence of $\mathrm{C}=\mathrm{O}$ bands in the $1698-1723 \mathrm{~cm}^{-1}$ region for compounds $3 \mathbf{c}, \mathbf{3 f}, 3 \mathbf{i}$, and 31 . In the ${ }^{1} \mathrm{H}-\mathrm{NMR}$ spectra, the $\mathrm{D}_{2} \mathrm{O}$ exchangeable signal of the $\mathrm{NH}_{2}$ protons was recorded at 4.70-5.21 ppm. The interaction [43-46] of 4-aminopyrrolopyridine carbonitrile derivatives $\mathbf{3 a}-\mathbf{1}$ with formic acid led to the formation of corresponding pyrimidin-4-one derivatives $4 a-1$ in yields ranging from $52 \%-87 \%$. The structures of $4 a-1$ were elucidated on the basis of their spectra (IR, ${ }^{1} \mathrm{H}-\mathrm{NMR}$, and MS) and elemental analysis. For example, their IR spectra revealed the absence of $\mathrm{NH}_{2}$ and $\mathrm{CN}$ absorption bands which are present in the IR spectra of their precursors 3a-1, and also revealed the presence of $\mathrm{NH}$ and $\mathrm{CO}$ absorption bands in the 3336-3475 and $1682-1729 \mathrm{~cm}^{-1}$ regions, respectively. Moreover, the ${ }^{1} \mathrm{H}-\mathrm{NMR}$ spectra showed the expected aromatic signals as well as two singlet signals near $\delta 8.20$ and $8.45 \mathrm{ppm}$ assignable to the pyrimidine $\mathrm{CH}=\mathrm{N}$, and amidic $\mathrm{NH}$ protons, respectively. All synthesized compounds are listed in Table 1.
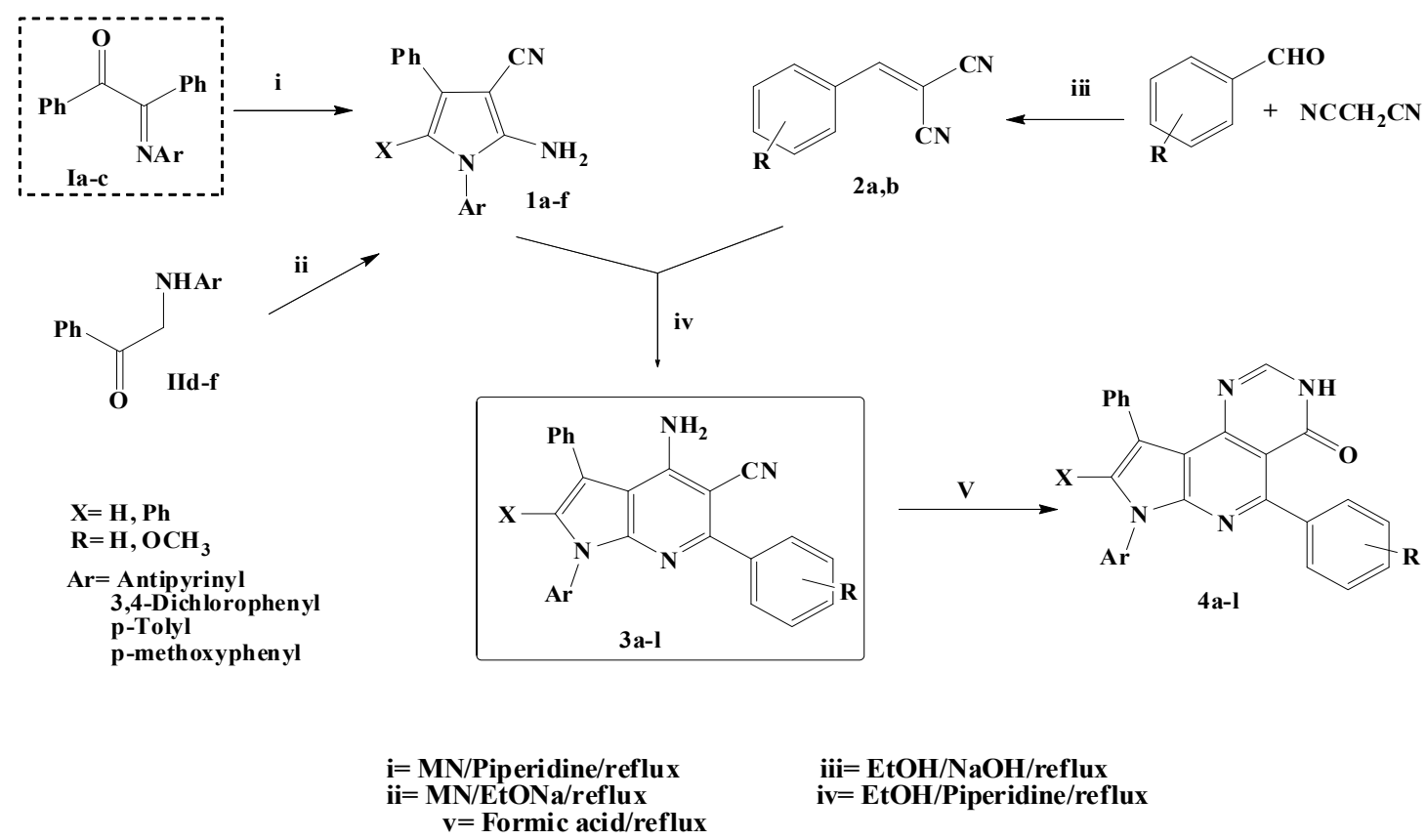

iii $=$ EtOH $/ \mathrm{NaOH} /$ reflux iv $=$ EtOH/Piperidine/reflux

Scheme 1. Synthesis of pyrrolopyridines (3a-1) and fused pyrimidines (4a-1).

Table 1. List of all synthesized compounds shown in Scheme 1.

\begin{tabular}{|c|c|c|c|c|c|c|c|}
\hline Compound Nos. & Ar & $X$ & $\mathbf{R}$ & Compound No. & Ar & $X$ & $\mathbf{R}$ \\
\hline Ia & 3,4-dichlorophenyl & $\mathrm{Ph}$ & - & $3 f$ & antipyrinyl & $\mathrm{Ph}$ & $\mathrm{H}$ \\
\hline $\mathrm{Ib}$ & $p$-methoxyphenyl & $\mathrm{Ph}$ & - & $3 g$ & $p$-tolyl & $\mathrm{H}$ & $\mathrm{OCH}_{3}$ \\
\hline Ic & antipyrinyl & $\mathrm{Ph}$ & 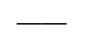 & $3 h$ & $p$-methoxyphenyl & $\mathrm{H}$ & $\mathrm{OCH}_{3}$ \\
\hline IId & $p$-tolyl & $\mathrm{H}$ & 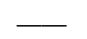 & $3 \mathbf{i}$ & antipyrinyl & $\mathrm{H}$ & $\mathrm{OCH}_{3}$ \\
\hline IIe & $p$-methoxyphenyl & $\mathrm{H}$ & - & $3 \mathbf{j}$ & 3,4-dichlorophenyl & $\mathrm{Ph}$ & $\mathrm{OCH}_{3}$ \\
\hline IIf & antipyrinyl & $\mathrm{H}$ & - & $3 k$ & $p$-methoxyphenyl & $\mathrm{Ph}$ & $\mathrm{OCH}_{3}$ \\
\hline $1 \mathrm{a}$ & $p$-tolyl & $\mathrm{H}$ & 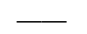 & 31 & antipyrinyl & $\mathrm{Ph}$ & $\mathrm{OCH}_{3}$ \\
\hline $1 b$ & $p$-methoxyphenyl & $\mathrm{H}$ & . & $4 a$ & $p$-tolyl & $\mathrm{H}$ & $\mathrm{H}$ \\
\hline $1 \mathrm{c}$ & antipyrinyl & $\mathrm{H}$ & - & $4 b$ & p-methoxyphenyl & $\mathrm{H}$ & $\mathrm{H}$ \\
\hline 1d & $p$-tolyl & $\mathrm{Ph}$ & - & $4 c$ & antipyrinyl & $\mathrm{H}$ & $\mathrm{H}$ \\
\hline $1 e$ & $p$-methoxyphenyl & $\mathrm{Ph}$ & . & $4 d$ & 3,4-dichlorophenyl & $\mathrm{Ph}$ & $\mathrm{H}$ \\
\hline 1f & antipyrinyl & $\mathrm{Ph}$ & 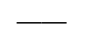 & $4 e$ & $p$-methoxyphenyl & $\mathrm{Ph}$ & $\mathrm{H}$ \\
\hline $2 a$ & & 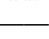 & $\mathrm{H}$ & $4 \mathrm{f}$ & antipyrinyl & $\mathrm{Ph}$ & $\mathrm{H}$ \\
\hline $2 b$ & - & 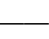 & $\mathrm{OCH}_{3}$ & $4 \mathrm{~g}$ & $p$-tolyl & $\mathrm{H}$ & $\mathrm{OCH}_{3}$ \\
\hline $3 a$ & $p$-tolyl & $\mathrm{H}$ & $\mathrm{H}$ & $4 \mathrm{~h}$ & $p$-methoxyphenyl & $\mathrm{H}$ & $\mathrm{OCH}_{3}$ \\
\hline $3 b$ & $p$-methoxyphenyl & $\mathrm{H}$ & $\mathrm{H}$ & $4 i$ & antipyrinyl & $\mathrm{H}$ & $\mathrm{OCH}_{3}$ \\
\hline $3 c$ & antipyrinyl & $\mathrm{H}$ & $\mathrm{H}$ & $4 j$ & 3,4-dichlorophenyl & $\mathrm{Ph}$ & $\mathrm{OCH}_{3}$ \\
\hline $3 d$ & 3,4-dichlorophenyl & $\mathrm{Ph}$ & $\mathrm{H}$ & $4 \mathbf{k}$ & p-methoxyphenyl & $\mathrm{Ph}$ & $\mathrm{OCH}_{3}$ \\
\hline $3 e$ & $p$-methoxyphenyl & $\mathrm{Ph}$ & $\mathrm{H}$ & 41 & antipyrinyl & $\mathrm{Ph}$ & $\mathrm{OCH}_{3}$ \\
\hline
\end{tabular}




\subsection{Anti-Inflammatory Assays}

Ten of the synthesized compounds $(3 \mathbf{b}-\mathbf{d}, \mathbf{3} \mathbf{g}-\mathbf{l}$, and $\mathbf{4 k}$ ) have been evaluated for their anti-inflammatory activity, using a method established by Harrk et al. [47]. Six of the tested compounds induced significant anti-inflammatory activity, comparable with that of diclofenac. Generally, the data listed in Table 2 indicated that the anti-inflammatory activity increased with time and their duration of action persisted for $4 \mathrm{~h}$ after the administration of the carrageenan.

Table 2. Anti-inflammatory activity of tested compounds, Results shown in paw size (mm, mean $\pm \mathrm{SD}$ ) and $\%$ inhibition over tested periods in comparison with control and standard drug.

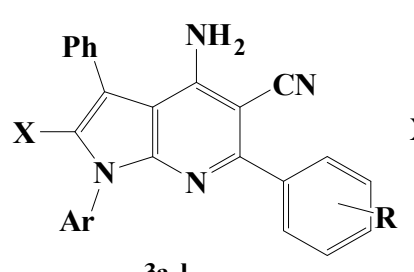

3a-1

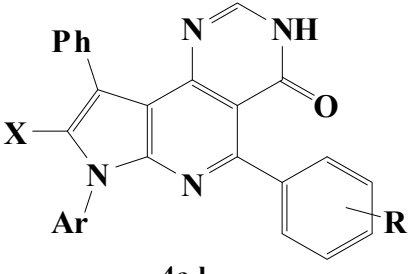

4a-I

\begin{tabular}{|c|c|c|c|c|c|c|c|c|}
\hline \multirow{2}{*}{ Compound } & \multicolumn{2}{|l|}{$1 \mathrm{~h}$} & \multicolumn{2}{|l|}{$2 \mathrm{~h}$} & \multicolumn{2}{|l|}{$3 \mathrm{~h}$} & \multicolumn{2}{|l|}{$4 \mathrm{~h}$} \\
\hline & Paw Size $(\mathrm{mm})$ & $\%$ Inh & Paw Size (mm) & $\%$ Inh & Paw Size $(\mathrm{mm})$ & $\%$ Inh & Paw Size (mm) & $\%$ Inh \\
\hline Control + ve & $5.86 \pm 0.31$ & 0 & $5.99 \pm 0.43$ & 0 & $6.11 \pm 0.42$ & 0 & $6.01 \pm 0.46$ & 0 \\
\hline Diclofenac & $4.11 \pm 0.19^{* * *}$ & 29.86 & $3.93 \pm 0.21 * * *$ & 34.39 & $3.64 \pm 0.20 * * *$ & 40.43 & $3.35 \pm 0.27^{* * *}$ & 44.26 \\
\hline $3 b$ & $5.09 \pm 0.36^{*}$ & 13.20 & $4.93 \pm 0.51 * *$ & 17.71 & $4.69 \pm 0.31^{* * *}$ & 23.24 & $4.61 \pm 0.27^{* * *}$ & 23.30 \\
\hline $3 c$ & $5.49 \pm 0.37$ & 6.31 & $4.81 \pm 0.32 * * *$ & 19.70 & $4.76 \pm 0.12 * * *$ & 22.10 & $4.61 \pm 0.34^{* * *}$ & 23.29 \\
\hline $3 d$ & $5.36 \pm 0.34$ & 8.53 & $5.62 \pm 0.46$ & 6.18 & $5.76 \pm 0.38$ & 5.73 & $5.63 \pm 0.48$ & 6.32 \\
\hline $3 g$ & $5.49 \pm 0.17$ & 6.31 & $5.41 \pm 0.24$ & 9.68 & $5.40 \pm 0.47$ & 11.62 & $5.32 \pm 0.48$ & 11.48 \\
\hline $3 \mathrm{~h}$ & $4.91 \pm 0.25^{* *}$ & 16.21 & $4.73 \pm 0.43^{* * *}$ & 21.04 & $4.71 \pm 0.46^{* * *}$ & 22.91 & $4.63 \pm 0.48^{* * *}$ & 22.96 \\
\hline $3 \mathbf{i}$ & $4.59 \pm 0.56^{* * *}$ & 21.67 & $4.43 \pm 0.42 * * *$ & 26.04 & $4.32 \pm 0.39 * * *$ & 29.30 & $4.13 \pm 0.53^{* * *}$ & 31.28 \\
\hline $3 \mathbf{j}$ & $5.69 \pm 0.41$ & 2.90 & $4.86 \pm 0.40 * *$ & 18.87 & $4.55 \pm 0.52 * * *$ & 25.53 & $4.21 \pm 0.43^{* * *}$ & 29.95 \\
\hline $3 \mathbf{k}$ & $5.44 \pm 0.25$ & 7.17 & $5.39 \pm 0.37$ & 10.02 & $5.34 \pm 0.52$ & 12.60 & $5.18 \pm 0.50$ & 13.81 \\
\hline 31 & $4.69 \pm 0.28^{* * *}$ & 19.97 & $4.19 \pm 0.24^{* * *}$ & 30.05 & $3.89 \pm 0.37^{* * *}$ & 36.33 & $3.81 \pm 0.34^{* * *}$ & 36.61 \\
\hline $4 k$ & $5.51 \pm 0.34$ & 5.97 & $5.47 \pm 0.32$ & 8.69 & $5.36 \pm 0.31$ & 12.28 & $5.14 \pm 0.43$ & 14.48 \\
\hline
\end{tabular}

Paw size $(\mathrm{mm})($ Mean $\pm \mathrm{SE}){ }^{* * *} p<0.001$ (Highly Significant), ${ }^{* *} p<0.01$ (Moderate significant), ${ }^{*} p<0.05$ (Significant);

$\%$ inhibition $=\frac{[\text { Control-Tested }]}{[\text { Control }]} \times 100$.

Compound 31 exerted manifestly significant activities compared to a standard drug at all-time intervals post-carrageenan $(\approx 19.97 \%, \approx 30.05 \%, \approx 36.33 \%$ and $\approx 36.61 \%$ inhibition at 1 st, 2 nd, 3rd and 4 th hour interval post-carrageenan administration). The activity profile was the same as that of the standard drugs (increasing response with time). Compound $3 \mathbf{i}$ exerted noticeable activities compared to the standard drugs at the 1 st, 2 nd, 3rd and 4 th hour post-carrageenan $(\approx 21.67 \%, \approx 26.04 \%, \approx 29.3 \%$ and $\approx 31.28 \%$ inhibition at 1 st, 2 nd, 3 rd and 4 th hour interval post-carrageenan). The activity profile was the same as that of the standard drugs (response increasing with time), yet the activity shown by compounds $\mathbf{3 b}, \mathbf{3 c}, \mathbf{3 h}$, and $\mathbf{3} \mathbf{j}$ over all tested intervals was modest but still significant. Compounds $\mathbf{3 c}$ and $\mathbf{3} \mathbf{j}$ showed increased activity from the second to fourth hours. Compounds $\mathbf{3 d}, \mathbf{3 g}$, $3 \mathbf{k}$ and $\mathbf{4 k}$ were all inactive over all tested periods and have shown percentages of inhibition from $7 \%$ to $14 \%$ at the 1 st to 4 th hour, respectively. Compounds $\mathbf{3 b}, \mathbf{3 c}, \mathbf{3 h}$, and $\mathbf{3 j}$ exhibited moderate anti-inflammatory activity compared to the standard drugs (response increasing with time) that improved over time, yet the activity shown was small, but still significant, for compounds $\mathbf{3 b}, \mathbf{3 c}, \mathbf{3 h}$ and $\mathbf{3 j}$ over all tested intervals. Compounds $\mathbf{3} \mathbf{j}$ showed increased activity from the second till the fourth hours. On the other hand, the lowest anti-inflammatory activity has been observed in compounds $\mathbf{3 d}, \mathbf{3 g}$, 3k and $4 \mathbf{k}$ over all tested periods, showing \% inhibitions $<7$ till $14.48 \%$ at the 1 st to 4 th hour, respectively, and are indicated as inactive.

\subsection{Docking and Modelling}

The free binding energy is directly proportional to the constrained binding constant whereby a higher $\Delta G$ value represents good binding. The clash score describes the degree of fitting and if a 
compound is at an optimum distance from the specified residues or if it is very close. The less the clash score, the more the mode of binding is preferred. The COX-2 enzyme binding site contains a number of residues such as Ser 530, Tyr 355, Trp 387, Arg 120, Glu 524 and Gln 192. The well-known COX-2 inhibitors did not bind to all of these residues at the same time. It has been reported [48] that ibuprofen for example interacts only with Arg 120 with an electrostatic bond. On the other hand diclofenac forms hydrogen bonds with Tyr 355.

In this study a number of substituted pyrrolo[2.3-b]pyridine derivatives (3b-d, $\mathbf{3 g}-\mathbf{1}$, and $4 \mathbf{k})$ have been synthesized and tested for their anti-inflammatory activity. A molecular docking study was done to predict the binding mode of the tested compounds and to interpret their activity.

The docking scores almost matched the biological results in the ranking the compounds $3 \mathbf{b}, 3 \mathbf{c}$, $\mathbf{3 h}, \mathbf{3 i}, \mathbf{3 j}$ and $\mathbf{3 1}$. Compound $3 \mathbf{l}$ (an antipyrinyl derivative) with the top ranked docking score $(-12.23)$ was also the most biologically active (as shown in Tables 2 and 3). It showed the least clash score (2.51) when compared with the rest of the series and also diclofenac with a 5.2 clash score. The best binding pose of compound 31 showed a hydrogen bond formed between the $\mathrm{C}=\mathrm{O}$ of the pyrazole-one moiety and the -OH group of Tyr 355. Furthermore, other interactions by its nitrile group and both Glu 520 and Pro 86 have been observed (Figure 2).

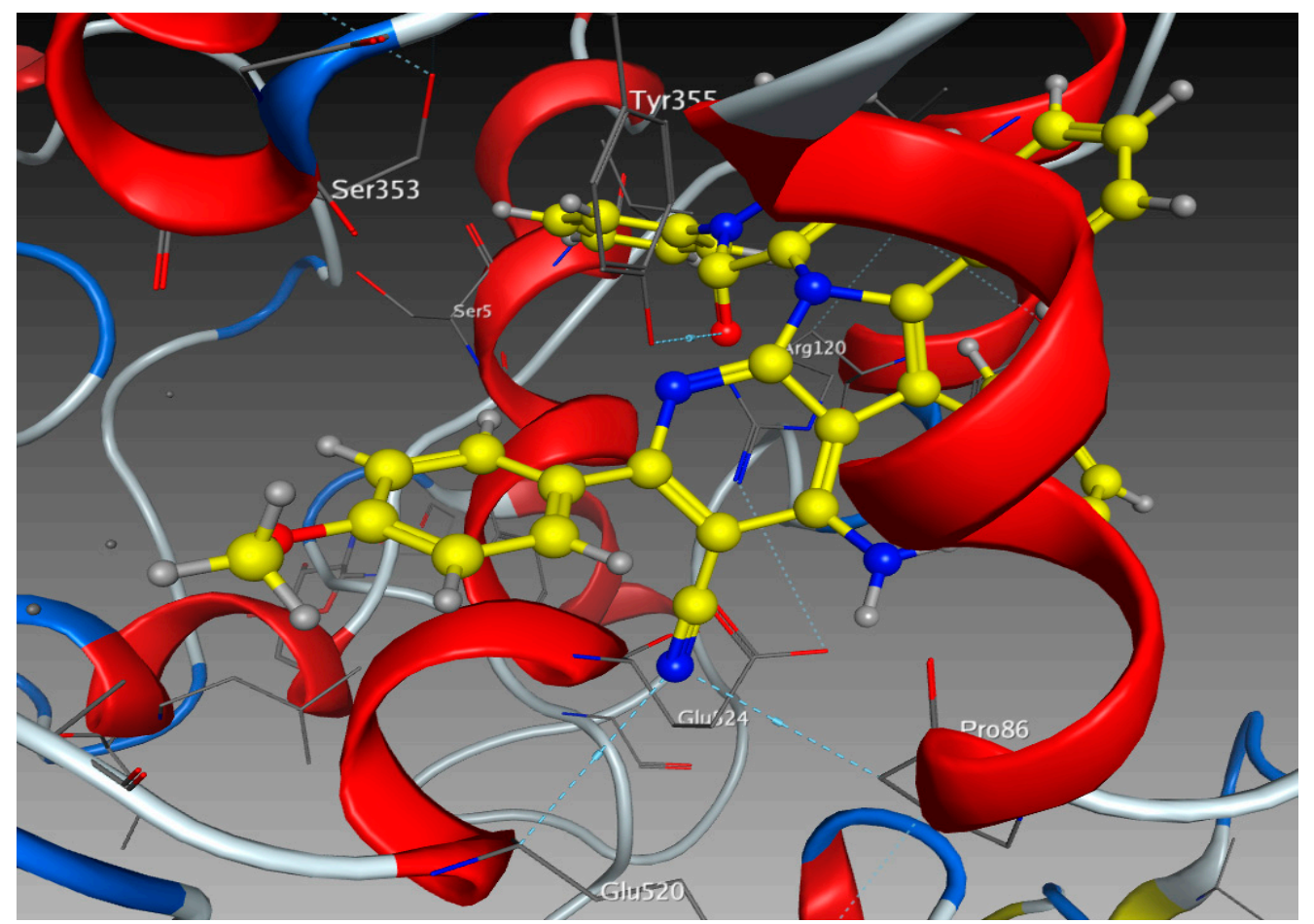

Figure 2. The best binding mode of compound 31 .

On the other hand compound 3j (a 3,4-dichlorophenyl derivative) with $-11.42 \mathrm{kcal} / \mathrm{mol}$ score contains a halo-substituted aromatic ring that encourages the formation of $\pi-\pi$ interactions with the aromatic ring of Tyr 355 and that has been illustrated clearly, when the halo-substituted ring was parallel to the aromatic ring of Tyr 355 in one of docked the poses of compound $3 \mathbf{j}$ (Figure 3 ). From the docking results and observations, the aminopyrrolo[2,3- $b$ ]pyridine-5-carbonitrile moiety linked with substituted pyrazole-3-one scaffold that was in both compounds 31 and $3 \mathbf{j}$ would have been a good scaffold with excellent binding to COX-2 and might need further studies for selection of the best substituent groups with high predicted activities. Some of the docked compounds showed a shift from the binding site and interacted with other residues as in the case of compound $4 \mathbf{k}$ ( $p$-methoxyphenyl derivative) that showed hydrogen bonds with Ser 119 and Tyr 115 and hence, its clash score was the highest (7.72). 


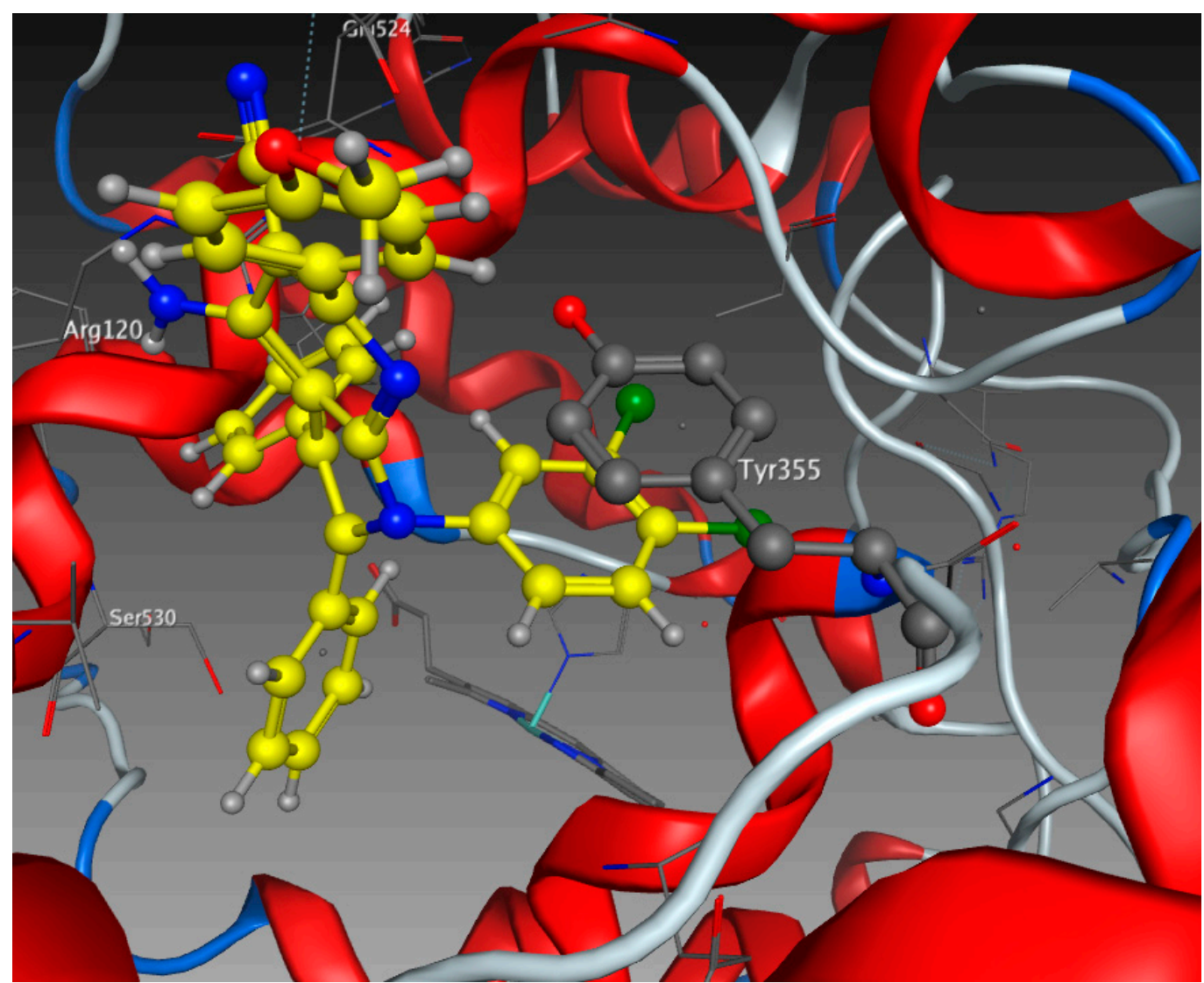

Figure 3. The best binding mode of compound $\mathbf{3 j}$.

The structure activity relationship is illustrated according to all results in Figure 4 . The docking results are summarized in Table 3 in which both free binding energy $(\mathrm{kcal} / \mathrm{mol})$ and clash scores have been computed.

Table 3. Free binding energy and clash score of all tested compounds and Diclofenac (standard COX Inhibitor).

\begin{tabular}{cccc}
\hline Compound & $\boldsymbol{\Delta}$ G Free Binding Energy $\mathbf{( K c a l / m o l )}$ & Clash & Interacted Residues \\
\hline Diclofenac & -16.85 & 5.2 & Tyr 355 \\
3b & -10.70 & 3.91 & Try 355 and Ser 530 \\
3c & -10.12 & 3.11 & Ser 530 and Tyr 355 \\
3d & -7.95 & 7.47 & Tyr 355 \\
3g & -7.06 & 7.21 & Arg 120 \\
3h & -10.52 & 3.45 & Arg 120 \\
3i & -11.25 & 3.50 & Tyr 385 and Ser 530 \\
3j & -11.42 & 2.87 & Tyr 355 \\
3k & -7.62 & 6.95 & Ser 119 \\
31 & -12.23 & 2.51 & Ser 530 and Tyr 355 \\
$\mathbf{4 k}$ & -8.01 & 7.72 & Ser 119 and Tyr 115 \\
\hline
\end{tabular}




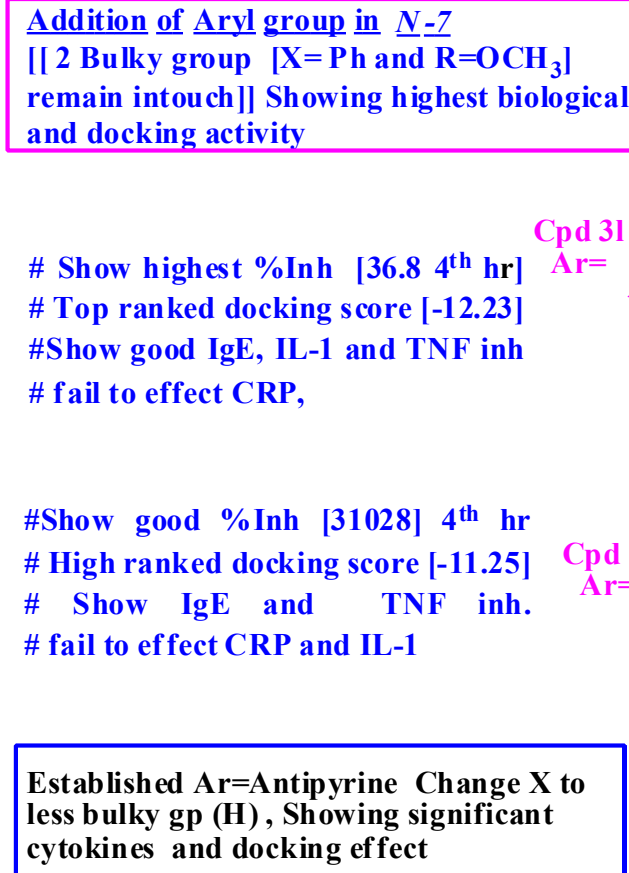

\# Show highest \%Inh $\left[36.84^{\text {th }}\right.$ hr $]$ Ar= \# Top ranked docking score [-12.23] \#Show good IgE, IL-1 and TNF inh \# fail to effect CRP,

\#Show good \%Inh [31028] $4^{\text {th }}$ hr \# High ranked docking score [-11.25] \# Show IgE and TNF inh. \# fail to ef fect CRP and IL-1 Established Ar=Antipyrine Change $X$ to
less bulky gp (H), Showing significant

cytokines and docking ef fect

\#Show good \%Inh $\left[29.95,4^{\text {th }} \mathrm{hr}\right]$

\# Good ranked docking score [-11.42]

\# Show IgE , and IL-1 inh.

\# fail to ef fect CRP and TNF

\section{Cpd $3 \mathrm{j}$} Ar= antipyrine $\mathrm{R}=\mathrm{OCH}_{3} \quad \mathrm{X}=\mathrm{H}$
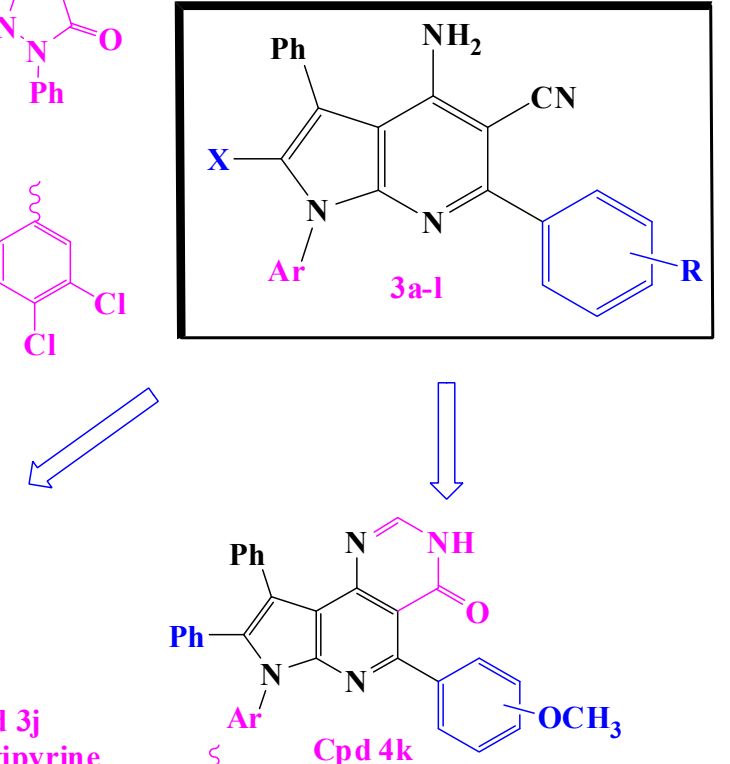

Cpd 4k

$\mathrm{OCH}_{3}$

Cyclization to pyrimidine unfortunately

dec activity and af finity in all intervals

$\mathrm{OCH}_{3} \%$ inh. $[14$ at 4 th $\mathrm{hr}]$ and docking score $=-8$
Established aryl and $\mathrm{X}=(\mathrm{H})$, Showing moderate anti-inlfammatory and docking effect

Cpd $3 \mathrm{~h}$

$\mathrm{R}=\mathrm{OCH}_{3}$

For both $\underline{3 b} \underline{\text { and }} \underline{3 h}$

\#Show good \%Inh [23, 4th $\left.^{\text {hr}}\right]$

\# Good ranked docking score [-10]

$\mathrm{OCH}_{3}$ \# indicate weak sharing of Ar moiety in activity

Cpd 3b

$\mathbf{R}=\mathbf{H}$

Established $X=(P h)$, Showing no an ti-

in lf ammatory and/or docking ef fect

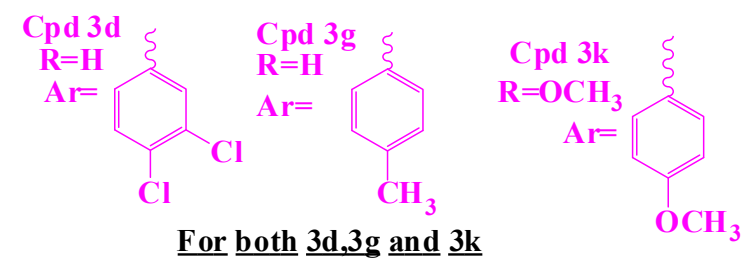

For both $\underline{3 d, 3 g}$ and $\underline{3 k}$

$\mathrm{OCH}_{3}$

Show no activity \% Inh $\left[6\right.$ to $13,4^{\text {th }} \mathrm{hr}$

\# Bad ranked docking score [-6 to -8 ]

\# indicate weak sharing of bulky gp at

pyrrole moiety in activity.

\#Show good \% Inh [23.29, $\left.4^{\text {th }} \mathrm{hr}\right] \quad$ Cpd 3c

\# Good ranked docking score [-10] Ar= antipyrine

\# Show IgE and CRP inh. $\mathbf{R}=\mathbf{H} \quad \mathbf{X}=\mathbf{H}$

\# fail to effect TNFand IL-1

Figure 4. SAR and discussion for all bioassay and docking studies performed on the tested compounds. 


\subsection{Inflammatory Mediators Assay}

Inflammation is mediated by a variety of soluble factors [49-52], including a group of secreted polypeptides known as cytokines. Inflammatory cytokines [27] could be divided into two groups: those involved in acute inflammation (e.g., IL-1 (interleukin-1), TNF (tumor necrosis factor) and those responsible for chronic inflammation (cytokines mediating humoral responses IL-4, IL-5 and those mediating cellular responses IL-1, IL-2). Some cytokines, such as IL-1, significantly contribute to both acute and chronic inflammation. The role of IL-1 in inflammation $[53,54]$ could be distinct to its own ability to trigger fever by enhancing prostaglandin E2 (PGE2) synthesis by the vascular endothelium of the hypothalamus and $\mathrm{T}$ cell proliferation stimulation. In addition, IL-1 elicited the release of histamine from mast cells at the site of inflammation. Histamine [50,55-57] then triggers early vasodilation and increase of vascular permeability. However, one of the first described [55,57-59] pharmacological roles of histamine has its ability to mimic anaphylaxis and has since been demonstrated to play a major role in inflammatory processes. In order to prevent inflammation, the mode of action of both inflammatory mediators and anti-inflammatory mediators must be well defined. Literature $[60,61]$ has indicated that inflammatory cytokines affect the cells of the immune system migrating to the site of inflammation. Due to the action of inflammatory cytokines, cells tend to produce excessive amounts of inflammatory PGE2, COX-2, phospholipase, and others.

It is worth mentioning that inflammatory cytokines have stimulated [62-65] cells to synthesize other inflammatory cytokines, namely, IL-1 $\beta$, TNF- $\alpha$, IL-6, IL-8, and chemokines. The anti-inflammatory cytokines are a series of immune-regulatory molecules $[34,50,66,67]$ that control the pro-inflammatory cytokine response. Anti-inflammatory cytokines have the ability to inhibit the synthesis of IL-1, tumor necrosis factor (TNF), and other major pro-inflammatory cytokines. Recently, in vivo and in vitro studies [68-70] showed that the effects of TNF- $\alpha$ have been parallel to or synergistic with those of IL-1 $\beta$. However, the precise roles $[69,70]$ that TNF- $\alpha$ and IL-1 $\beta$ play in pro-inflammation remain unknown.

\section{Discussion}

In the light of the above conclusions about the importance of pro-inflammatory cytokines and other inflammatory mediators in chronic disease, research is urgently needed to develop small molecules targeting cytokines to control their actions. Several NSAIDs have been known to affect the production or actions of cytokines [10,12,71-73] and this property has been considered to be a component of their actions, whether positive or negative. Yet, among NSAIDs, some might increase the production of interleukin-1 (IL-1 $\beta$ ) or tumor necrosis factor (TNF- $\alpha$ ) like indomethacin (nonselective inhibitor of COX-1 and COX-2) and these effects have been considered important in the development of GI (gastrointestinal) ulcers and asthma attributed to these drugs. However, other NSAIDs inhibit TNF- $\alpha$, as nimesulide (a preferential COX-2 inhibitor), and ibuprofen (a nonselective COX-2 inhibitor) [74,75].

As it has been shown in this research, four compounds exhibiting the highest in vivo anti-inflammatory and best docking score (namely; 3c, 3i, 3j and 31) have been tested for their effects on cytokines (namely; IL-1 $\beta, \mathrm{TNF}-\alpha$ ), CRP, histamine and immunoglobulin $\mathrm{E}$ (IgE), comparing results with the standard drug diclofenac.

The results of inflammatory mediators confirmed those of in vivo anti-inflammatory and docking assays, as shown in Table 4. In general all compounds (3c, 3i, 3j, and $\mathbf{3 1}$ ), as well as diclofenac, significantly inhibit IgE compared with the control group. Compound 31 showed the highest percentage of inhibition and top ranked docking score, exhibited a significant lower level of IL1- $\beta$ and TNF- $\alpha$ compared with the control group. There is no significant difference in IgE and IL1- $\beta$ levels between 31 and diclofenac. Administration of compound 3i showed a significantly lower level of histamine and TNF- $\alpha$ compared with the control group. IL-1 $\beta$ level of $\mathbf{3 j}$, was significantly lower than that in the control group. Compound $3 \mathrm{c}$ was able to decrease CRP and TNF- $\alpha$ cytokine. All results and discussion are illustrated in details in Figure 4. 
Table 4. Active compounds against inflammatory mediators in comparison with diclofenac.

\begin{tabular}{|c|c|c|c|c|c|}
\hline $\begin{array}{c}\text { Active } \\
\text { Compound/Drug }\end{array}$ & Histamine $(\mu \mathrm{g} / \mathrm{L})$ & $\operatorname{IgE}(\mathrm{IU} / \mathrm{mL})$ & CRP (mg/L) & IL1- $\beta$ (ng/L) & $\mathrm{TNF}-\alpha(\mathrm{pg} / \mathrm{mL})$ \\
\hline Control & $0.936 \pm 0.024$ & $3.7 \pm 0.07$ & $10.4 \pm 0.89$ & $11.8 \pm 0.06$ & $28.83 \pm 0.19$ \\
\hline Diclofenac & $0.732 \pm 0.009$ & $1.7 \pm 0.31^{* * *}$ & $7.6 \pm 0.51 *$ & $8.9 \pm 0.05 *$ & $26.28 \pm 1.46$ \\
\hline $3 c$ & $0.784 \pm 0.016$ & $1.5 \pm 0.28^{* * *}$ & $6.6 \pm 0.80 *$ & $11.58 \pm 0.42$ & $31.1 \pm 0.10$ \\
\hline $3 \mathbf{i}$ & $0.338 \pm 0.195^{* *}$ & $1.68 \pm 0.06^{* * *}$ & $10.8 \pm 0.0 .37$ & $11.18 \pm 0.90$ & $20.3 \pm 1.42 *$ \\
\hline $3 \mathbf{j}$ & $0.762 \pm 0.114$ & $2.14 \pm 0.05^{* * *}$ & $11.4 \pm 1.20$ & $7.44 \pm 0.89^{* * *}$ & $26.88 \pm 3.25$ \\
\hline 31 & $0.819 \pm 0.05$ & $1.5 \pm 0.07^{* * *}$ & $12.4 \pm 0.51$ & $7.6 \pm 0.34^{* * *}$ & $16.1 \pm 1.50 * *$ \\
\hline
\end{tabular}

\section{Materials and Methods}

\subsection{General Information}

All commercial chemicals used as starting materials and reagents in this study have been purchased from Merck (Darmstadt, Germany) and were of reagent grade. All melting points are uncorrected and were measured using an Electrothermal IA 9100 apparatus (Shimadzu, Kyoto, Japan); IR spectra have been recorded as potassium bromide pellets on a Perkin-Elmer 1650 spectrophotometer (Waltham, MA, USA). ${ }^{1} \mathrm{H}-\mathrm{NMR}$ spectra were determined on a Mercury $300 \mathrm{MHz}$ spectrometer (Varian, Cambridge, UK) and chemical shifts have been expressed as ppm against TMS as an internal reference. Mass spectra have been recorded at $70 \mathrm{eV}$ on an EI MS-QP 1000 EX instrument (Shimadzu). Microanalyses have been performed using a Vario Elmentar apparatus (Shimadzu, Kyoto, Japan). Column chromatography has performed on silica gel 60 (particle size $0.06-0.20 \mathrm{~mm}$, Merck). Compounds 1 and 2 have prepared as reported in literature [26-28,30]. The structures of all new compounds prepared in this paper have been confirmed by their spectral data.

\subsection{Synthesis}

\subsubsection{General Procedure for the Synthesis of Compounds 3a-1}

To a solution of $\mathbf{1 a}-\mathbf{f}(0.1 \mathrm{~mol})$ in ethanol $(30 \mathrm{~mL})$, an appropriate arylidenemalononitrile (benzylidine or $p$-methoxybenzylidenemalononitrile, $0.1 \mathrm{~mol}$ ) and piperidine $(2 \mathrm{~mL})$ were added. The reaction mixture was refluxed for $8 \mathrm{~h}$. The mixture was left to cool at room temperature then poured onto crushed ice, and neutralized with hydrochloric acid. The solid precipitate was filtered off, washed with water, and crystallized from ethanol to yield 3a-1.

4-Amino-5-cyano-3,6-diphenyl-1-(4-methylphenyl)-1H-pyrrolo[2,3-b]pyridine (3a). Yield: 80\%; m.p.: 203-205 ${ }^{\circ} \mathrm{C}$; IR (KBr) $v\left(\mathrm{~cm}^{-1}\right): 3467,3426\left(\mathrm{NH}_{2}\right), 2176(\mathrm{CN}), 1576(\mathrm{C}=\mathrm{N})$; MS (EI) $m / z: 400(\mathrm{M}+, 52 \%) ;{ }^{1} \mathrm{H}-\mathrm{NMR}$ (DMSO- $\left.d_{6}\right) \delta(\mathrm{ppm}): 2.4\left(\mathrm{~s}, 3 \mathrm{H}, \mathrm{CH}_{3}\right), 4.9\left(\mathrm{~s}, 2 \mathrm{H}, \mathrm{NH}_{2}, \mathrm{D}_{2} \mathrm{O}\right.$ exchangeable), 6.8-7.9 (m, 15H, Ar-H); Anal. Calcd. for $\mathrm{C}_{27} \mathrm{H}_{20} \mathrm{~N}_{4}$ (400.47): C, 81.00; H, 5.00; N, 14.00\%. Found: $\mathrm{C}, 80.86 ; \mathrm{H}, 5.18 ; \mathrm{N}, 14.26 \%$.

4-Amino-5-cyano-3,6-diphenyl-1-(4-methoxyphenyl)-1H-pyrrolo[2,3-b]pyridine (3b). Yield: 94\%; m.p.: 189-191 ${ }^{\circ} \mathrm{C}$; IR (KBr) $v\left(\mathrm{~cm}^{-1}\right): 3426,3411\left(\mathrm{NH}_{2}\right), 2215(\mathrm{CN}), 1597(\mathrm{C}=\mathrm{N}) ; \mathrm{MS}(\mathrm{EI}) \mathrm{m} / z: 416(\mathrm{M}+, 43 \%) ;{ }^{1} \mathrm{H}-\mathrm{NMR}$ (DMSO- $\left.d_{6}\right) \delta(\mathrm{ppm}): 3.54\left(\mathrm{~s}, 3 \mathrm{H}, \mathrm{OCH}_{3}\right), 5.1\left(\mathrm{~s}, 2 \mathrm{H}, \mathrm{NH}_{2}, \mathrm{D}_{2} \mathrm{O}\right.$ exchangeable), 6.9-7.9 (m, 15H, Ar-H); Anal. Calcd. for $\mathrm{C}_{27} \mathrm{H}_{20} \mathrm{~N}_{4} \mathrm{O}$ (416.47): $\mathrm{C}, 77.88 ; \mathrm{H}, 4.81 ; \mathrm{N}, 13.46 \%$. Found: $\mathrm{C}, 77.81 ; \mathrm{H}, 4.59 ; \mathrm{N}, 13.21$.

4-Amino-5-cyano-3,6-diphenyl-1-(1,5-dimethyl-3-oxo-2-phenyl-2,3-dihydro-1H-pyrazol-4-yl)-1H-pyrrolo[2,3-b] pyridine (3c). Yield: 78\%; m.p.: 182-184 ${ }^{\circ} \mathrm{C}$; IR (KBr) $v\left(\mathrm{~cm}^{-1}\right)$ : 3445, $3417\left(\mathrm{NH}_{2}\right), 2203(\mathrm{CN}), 1713$ $(\mathrm{C}=\mathrm{O}), 1588(\mathrm{C}=\mathrm{N}) ; \mathrm{MS}(\mathrm{EI}) \mathrm{m} / z: 496(\mathrm{M}+, 12.6 \%) ;{ }^{1} \mathrm{H}-\mathrm{NMR}\left(\mathrm{DMSO}-d_{6}\right) \delta(\mathrm{ppm}): 2.21\left(\mathrm{~s}, 3 \mathrm{H}, \mathrm{CH}_{3}\right)$, $3.4\left(\mathrm{~s}, 3 \mathrm{H}, \mathrm{NCH}_{3}\right), 5.0\left(\mathrm{~s}, 2 \mathrm{H}, \mathrm{NH}_{2}, \mathrm{D}_{2} \mathrm{O}\right.$ exchangeable), 7.1-8.0 (m, 16H, Ar-H); Anal. Calcd. for $\mathrm{C}_{31} \mathrm{H}_{24} \mathrm{~N}_{6} \mathrm{O}$ (496.56): C, 75.00; H, 4.84; N, 16.94\%. Found: $\mathrm{C}, 75.18 ; \mathrm{H}, 4.66 ; \mathrm{N}, 16.72 \%$.

4-Amino-5-cyano-2,3,6-triphenyl-1-(3,4-dichlorophenyl)-1H-pyrrolo[2,3-b]pyridine (3d). Yield: 57\%; m.p.: 134-136 ${ }^{\circ} \mathrm{C}$; IR (KBr) $v\left(\mathrm{~cm}^{-1}\right): 3425,3418\left(\mathrm{NH}_{2}\right), 2211(\mathrm{CN}), 1588(\mathrm{C}=\mathrm{N})$; $\mathrm{MS}(\mathrm{EI}) \mathrm{m} / z: 530(\mathrm{M}+, 26 \%$; 
$\mathrm{M}+2,11 \% ; \mathrm{M}+4,2.2 \%) ;{ }^{1} \mathrm{H}-\mathrm{NMR}$ (DMSO- $\left.d_{6}\right) \delta$ (ppm):5.21 (s, 2H, $\mathrm{NH}_{2}, \mathrm{D}_{2} \mathrm{O}$ exchangeable), 7.0-8.1 (m, $18 \mathrm{H}, \mathrm{Ar}-\mathrm{H})$; Anal. Calcd. for $\mathrm{C}_{32} \mathrm{H}_{20} \mathrm{Cl}_{2} \mathrm{~N}_{4}$ (531.43): $\mathrm{C}, 72.45 ; \mathrm{H}, 3.77 ; \mathrm{Cl}, 13.21 ; \mathrm{N}, 10.57 \%$. Found: C, 72.19; $\mathrm{H}, 3.46 ; \mathrm{Cl}, 13.46 ; \mathrm{N}, 10.71 \%$.

4-Amino-5-cyano-2,3,6-triphenyl-1-(4-methoxyphenyl)-1H-pyrrolo[2,3-b] pyridine (3e). Yield: 88\%; m.p.: 234-236 ${ }^{\circ} \mathrm{C}$; IR (KBr) $v\left(\mathrm{~cm}^{-1}\right)$ : 3365, $3322\left(\mathrm{NH}_{2}\right), 2219(\mathrm{CN}), 1618(\mathrm{C}=\mathrm{N}), 1245$ (C-O); MS (EI) $\mathrm{m} / z$ : $492(\mathrm{M}+, 54 \%) ;{ }^{1} \mathrm{H}-\mathrm{NMR}$ (DMSO- $\left.d_{6}\right) \delta(\mathrm{ppm}): 3.6\left(\mathrm{~s}, 3 \mathrm{H}, \mathrm{OCH}_{3}\right), 4.9\left(\mathrm{~s}, 2 \mathrm{H}, \mathrm{NH}_{2}, \mathrm{D}_{2} \mathrm{O}\right.$ exchangeable), 6.8-8.0 (m, 19H, Ar-H); Anal. Calcd. for $\mathrm{C}_{33} \mathrm{H}_{24} \mathrm{~N}_{4} \mathrm{O}$ (492.57): C, 80.49; H, 4.88; N, 11.38\%. Found: C, $80.15 ; \mathrm{H}, 5.04 ; \mathrm{N}, 11.71 \%$.

4-Amino-5-cyano-2,3,6-triphenyl-1-(1,5-dimethyl-3-oxo-2-phenyl-2,3-dihydro-1H-pyrazol-4-yl)-1H-pyrrolo [2,3-b]pyridine (3f). Yield: 39\%; m.p.: 172-174 ${ }^{\circ} \mathrm{C}$; IR (KBr) $v\left(\mathrm{~cm}^{-1}\right)$ : 3332, $3316\left(\mathrm{NH}_{2}\right), 2220(\mathrm{CN}), 1698$ $(\mathrm{C}=\mathrm{O}), 1605(\mathrm{C}=\mathrm{N}) ; \mathrm{MS}(\mathrm{EI}) \mathrm{m} / z: 572(\mathrm{M}+, 30.4 \%) ;{ }^{1} \mathrm{H}-\mathrm{NMR}$ (DMSO-d 6 ) $\delta(\mathrm{ppm}): 2.25\left(\mathrm{~s}, 3 \mathrm{H}, \mathrm{CH}_{3}\right)$, $3.5\left(\mathrm{~s}, 3 \mathrm{H}, \mathrm{NCH}_{3}\right), 5.21\left(\mathrm{~s}, 2 \mathrm{H}, \mathrm{NH}_{2}, \mathrm{D}_{2} \mathrm{O}\right.$ exchangeable), 6.8-8.0 (m, 20H, Ar-H); Anal. Calcd. for $\mathrm{C}_{37} \mathrm{H}_{28} \mathrm{~N}_{6} \mathrm{O}$ (572.66): C, 77.62; H, 4.90; N, 14.69\%. Found: C, 77.91; H, 4.96; N, $14.45 \%$.

4-Amino-5-cyano-3-phenyl-1-(4-methylphenyl)-6-(4-methoxyphenyl)-1H-pyrrolo [2,3-b]pyridine (3g). Yield: 71\%; m.p.: 208-210 ${ }^{\circ} \mathrm{C}$; IR (KBr) $v\left(\mathrm{~cm}^{-1}\right)$ : 3434, $3397\left(\mathrm{NH}_{2}\right), 2210(\mathrm{CN}), 1608(\mathrm{C}=\mathrm{N}), 1219$ (C-O); MS (EI) $m / z: 430(\mathrm{M}+, 53 \%) ;{ }^{1} \mathrm{H}-\mathrm{NMR}$ (DMSO-d $\left.d_{6}\right) \delta(\mathrm{ppm}): 2.3\left(\mathrm{~s}, 3 \mathrm{H}, \mathrm{CH}_{3}\right), 3.5\left(\mathrm{~s}, 3 \mathrm{H}, \mathrm{OCH}_{3}\right), 5.1(\mathrm{~s}, 2 \mathrm{H}$, $\mathrm{NH}_{2}, \mathrm{D}_{2} \mathrm{O}$ exchangeable), 6.9-7.9 (m, $\left.14 \mathrm{H}, \mathrm{Ar}-\mathrm{H}\right)$; Anal. Calcd. for $\mathrm{C}_{28} \mathrm{H}_{22} \mathrm{~N}_{4} \mathrm{O}$ (430.50): C, 78.14; $\mathrm{H}$, 5.12; N, $13.02 \%$. Found: C, 77.95; H, 5.36; N, $12.84 \%$.

4-Amino-5-cyano-3-phenyl-1,6-di(4-methoxyphenyl)-1H-pyrrolo[2,3-b]pyridine (3h). Yield: 68\%; m.p.: 202-204 ${ }^{\circ} \mathrm{C}$; IR ( $\left.\mathrm{KBr}\right) v\left(\mathrm{~cm}^{-1}\right): 3419,3382\left(\mathrm{NH}_{2}\right), 2217(\mathrm{CN}), 1616(\mathrm{C}=\mathrm{N}), 1234(\mathrm{C}-\mathrm{O}) ; \mathrm{MS}(\mathrm{EI}) \mathrm{m} / z: 446$ $(\mathrm{M}+, 18.7 \%) ;{ }^{1} \mathrm{H}-\mathrm{NMR}\left(\mathrm{DMSO}-d_{6}\right) \delta(\mathrm{ppm}): 3.51\left(\mathrm{~s}, 3 \mathrm{H}, \mathrm{OCH}_{3}\right), 3.7\left(\mathrm{~s}, 3 \mathrm{H}, \mathrm{OCH}_{3}\right), 5.2\left(\mathrm{~s}, 2 \mathrm{H}, \mathrm{NH}_{2}\right.$, $\mathrm{D}_{2} \mathrm{O}$ exchangeable), 6.9-8.1 (m, $\left.14 \mathrm{H}, \mathrm{Ar}-\mathrm{H}\right)$; Anal. Calcd. for $\mathrm{C}_{28} \mathrm{H}_{22} \mathrm{~N}_{4} \mathrm{O}_{2}(446.50)$ : C, 75.34; $\mathrm{H}, 4.93 ; \mathrm{N}$, $12.56 \%$. Found: $\mathrm{C}, 75.65 ; \mathrm{H}, 5.16 ; \mathrm{N}, 12.64 \%$.

4-Amino-5-cyano-3-phenyl-6-(4-methoxyphenyl)-1-(1,5-dimethyl-3-oxo-2-phenyl-2,3-dihydro-1H-pyrazol-4-yl)1H-pyrrolo[2,3-b]pyridine (3i). Yield: 63\%; m.p.: 195-193 ${ }^{\circ} \mathrm{C}$; $\mathrm{IR}(\mathrm{KBr}) v\left(\mathrm{~cm}^{-1}\right): 3387,3356\left(\mathrm{NH}_{2}\right), 2208$ $(\mathrm{CN}), 1716(\mathrm{C}=\mathrm{O}), 1605(\mathrm{C}=\mathrm{N}), 1227(\mathrm{C}-\mathrm{O}) ; \mathrm{MS}(\mathrm{EI}) \mathrm{m} / z$ : $526(\mathrm{M}+, 37.5 \%) ;{ }^{1} \mathrm{H}-\mathrm{NMR}\left(\mathrm{DMSO}-d_{6}\right) \delta$ (ppm): 2.32 (s, $\left.3 \mathrm{H}, \mathrm{CH}_{3}\right), 3.5\left(\mathrm{~s}, 3 \mathrm{H}, \mathrm{OCH}_{3}\right), 3.7\left(\mathrm{~s}, 3 \mathrm{H}, \mathrm{NCH}_{3}\right), 4.81\left(\mathrm{~s}, 2 \mathrm{H}, \mathrm{NH}_{2}, \mathrm{D}_{2} \mathrm{O}\right.$ exchangeable), 6.9-8.2 (m, 15H, Ar-H); Anal. Calcd for $\mathrm{C}_{32} \mathrm{H}_{26} \mathrm{~N}_{6} \mathrm{O}_{2}$ (526.59): C, 73.00; H, 4.94; N, 15.97\%. Found: C, $72.76 ; \mathrm{H}, 5.23 ; \mathrm{N}, 15.71 \%$.

4-Amino-5-cyano-2,3-diphenyl-1-(3,4-dichlorophenyl)-6-(4-methoxyphenyl)-1H-pyrrolo[2,3-b]pyridine (3j). Yield: 41\%; m.p.: 154-156 ${ }^{\circ} \mathrm{C}$; IR ( $\left.\mathrm{KBr}\right) v\left(\mathrm{~cm}^{-1}\right)$ : 3314, $3293\left(\mathrm{NH}_{2}\right), 2205(\mathrm{CN}), 1568(\mathrm{C}=\mathrm{N}), 1234(\mathrm{C}-\mathrm{O})$; MS (EI) $m / z: 560(\mathrm{M}+, 100 \% ; \mathrm{M}+2,65 \% ; \mathrm{M}+4,12.8 \%) ;{ }^{1} \mathrm{H}-\mathrm{NMR}$ (DMSO- $\left.d_{6}\right) \delta$ (ppm): $3.57(\mathrm{~s}, 3 \mathrm{H}$, $\left.\mathrm{OCH}_{3}\right), 4.7$ (s, 2H, $\mathrm{NH}_{2}, \mathrm{D}_{2} \mathrm{O}$ exchangeable), $6.8-7.9\left(\mathrm{~m}, 17 \mathrm{H}\right.$, Ar-H); Anal. Calcd. for $\mathrm{C}_{33} \mathrm{H}_{22} \mathrm{Cl}_{2} \mathrm{~N}_{4} \mathrm{O}$ (561.46): C, 70.71; H, 3.93; N, 10.00\%. Found: C, 70.93; H, 4.13; N, 10.24\%.

4-Amino-5-cyano-2,3-diphenyl-1,6-di(4-methoxyphenyl)-1H-pyrrolo[2,3-b]pyridine (3k). Yield: 82\%; m.p.: 231-233 ${ }^{\circ} \mathrm{C}$; IR (KBr) v ( $\left.\mathrm{cm}^{-1}\right)$ : 3274, $3245\left(\mathrm{NH}_{2}\right), 2224(\mathrm{CN}), 1603(\mathrm{C}=\mathrm{N}), 1235$ (C-O); MS (EI) m/z: 522 $(\mathrm{M}+, 36 \%) ;{ }^{1} \mathrm{H}-\mathrm{NMR}\left(\mathrm{DMSO}-d_{6}\right) \delta(\mathrm{ppm}): 3.62\left(\mathrm{~s}, 3 \mathrm{H}, \mathrm{OCH}_{3}\right), 3.7\left(\mathrm{~s}, 3 \mathrm{H}, \mathrm{NCH}_{3}\right), 5.0\left(\mathrm{~s}, 2 \mathrm{H}, \mathrm{NH}_{2}, \mathrm{D}_{2} \mathrm{O}\right.$ exchangeable), 6.9-8.0 (m, $18 \mathrm{H}, \mathrm{Ar}-\mathrm{H})$; Anal. Calcd. for $\mathrm{C}_{34} \mathrm{H}_{26} \mathrm{~N}_{4} \mathrm{O}_{2}$ (522.60): C, 78.16; H, 4.98; N, $10.73 \%$. Found: C, 78.45; H, 5.33; N, 10.89\%.

4-Amino-5-cyano-2,3-diphenyl-6-(4-methoxyphenyl)-1-(1,5-dimethyl-3-oxo-2-phenyl-2,3-dihydro-1H-pyrazol4-yl)-1H-pyrrolo[2,3-b]pyridine (31). Yield: 87\%; m.p.: $186-188^{\circ} \mathrm{C}$; $\mathrm{IR}(\mathrm{KBr}) v\left(\mathrm{~cm}^{-1}\right): 3367,3321\left(\mathrm{NH}_{2}\right)$, $2211(\mathrm{CN}), 1723(\mathrm{C}=\mathrm{O}), 1598(\mathrm{C}=\mathrm{N}), 1233(\mathrm{C}-\mathrm{O}) ; \mathrm{MS}(\mathrm{EI}) \mathrm{m} / z: 602(\mathrm{M}+, 67 \%) ;{ }^{1} \mathrm{H}-\mathrm{NMR}\left(\mathrm{DMSO}-d_{6}\right) \delta$ (ppm): $2.2\left(\mathrm{~s}, 3 \mathrm{H}, \mathrm{CH}_{3}\right), 3.54\left(\mathrm{~s}, 3 \mathrm{H}, \mathrm{OCH}_{3}\right), 3.6\left(\mathrm{~s}, 3 \mathrm{H}, \mathrm{NCH}_{3}\right), 4.9\left(\mathrm{~s}, 2 \mathrm{H}, \mathrm{NH}_{2}, \mathrm{D}_{2} \mathrm{O}\right.$ exchangeable), 6.9-8.0 (m, 19H, Ar-H); Anal. Calcd. for $\mathrm{C}_{38} \mathrm{H}_{30} \mathrm{~N}_{6} \mathrm{O}_{2}$ (602.68): C, 75.75; H, 4.98; N, 13.95\%. Found: C, $75.79 ; \mathrm{H}, 5.12 ; \mathrm{N}, 13.61 \%$. 


\subsubsection{General Procedure for the Synthesis of Compounds $4 \mathbf{a}-\mathbf{1}$}

The appropriate aminopyrrolopyridine 3a-1 (0.01 mol) was heated in formic acid $(20 \mathrm{~mL}, 85 \%)$ under reflux for $3 \mathrm{~h}$, cooled, poured onto ice water to give a precipitate, filtered off, dried, and crystallized from ethanol to yield compounds $4 \mathbf{a}-\mathbf{1}$.

5,9-Diphenyl-7-(4-methylphenyl)-3H-pyrrolo[2,3-b]pyrido[4,3-d]pyrimidin-4-one (4a). Yield: 82\%; m.p.: 226-228 ${ }^{\circ} \mathrm{C}$; IR (KBr) v ( $\left.\mathrm{cm}^{-1}\right): 3412(\mathrm{NH}), 1726(\mathrm{C}=\mathrm{O}), 1596(\mathrm{C}=\mathrm{N})$; MS (EI) $\mathrm{m} / z: 428(\mathrm{M}+, 44 \%)$; ${ }^{1} \mathrm{H}-\mathrm{NMR}\left(\mathrm{DMSO}-d_{6}\right) \delta$ (ppm): 2.34 (s, 3H, CH $), 6.8-7.9(\mathrm{~m}, 15 \mathrm{H}, \mathrm{Ar}-\mathrm{H}), 8.1(\mathrm{~s}, 1 \mathrm{H}, \mathrm{C}-2 \mathrm{H}), 8.3$ (s, $1 \mathrm{H}$, $\mathrm{NH}, \mathrm{D}_{2} \mathrm{O}$ exchangeable); Anal. Calcd. for $\mathrm{C}_{28} \mathrm{H}_{20} \mathrm{~N}_{4} \mathrm{O}$ (428.48): C, 78.50; H, 4.67; N, 13.08\%. Found: C, 78.82; H, 4.41; N, 13.23\%.

5,9-Diphenyl-7-(4-methoxyphenyl)-3H-pyrrolo[2,3-b]pyrido[4,3-d]pyrimidin-4-one (4b). Yield: 87\%; m.p.: 214-216 ${ }^{\circ} \mathrm{C}$; IR (KBr) $v\left(\mathrm{~cm}^{-1}\right): 3510(\mathrm{NH}), 1719$ (C=O), 1609 (C=N), $1234(\mathrm{C}-\mathrm{O})$; MS (EI) m/z: 444 (M+, 19.5\%); ${ }^{1} \mathrm{H}-\mathrm{NMR}\left(\mathrm{DMSO}-d_{6}\right) \delta(\mathrm{ppm}): 3.5$ (s, 3H, $\left.\mathrm{OCH}_{3}\right), 6.9-7.9(\mathrm{~m}, 15 \mathrm{H}, \mathrm{Ar}-\mathrm{H}), 8.12(\mathrm{~s}, 1 \mathrm{H}, \mathrm{C}-2 \mathrm{H})$, 8.3 (s, $1 \mathrm{H}, \mathrm{NH}, \mathrm{D}_{2} \mathrm{O}$ exchangeable); Anal. Calcd. for $\mathrm{C}_{28} \mathrm{H}_{20} \mathrm{~N}_{4} \mathrm{O}_{2}$ (444.48): C, 75.68; $\mathrm{H}, 4.50 ; \mathrm{N}, 12.61 \%$. Found: C, 75.87; H, 4.84; N, 12.33\%.

5,9-Diphenyl-7-(1,5-dimethyl-3-oxo-2-phenyl-2,3-dihydro-1H-pyrazol-4-yl)-3H-pyrrolo[2,3-b]pyrido[4,3-d] pyrimidin-4-one (4c). Yield: 68\%; m.p.: 219-221 ${ }^{\circ} \mathrm{C}$; IR (KBr) $v\left(\mathrm{~cm}^{-1}\right): 3451(\mathrm{NH}), 1706,1724(\mathrm{C}=\mathrm{O})$, 1617 (C=N); MS (EI) m/z: $524(\mathrm{M}+, 35 \%) ;{ }^{1} \mathrm{H}-\mathrm{NMR}\left(\mathrm{DMSO}-d_{6}\right) \delta(\mathrm{ppm}): 2.6\left(\mathrm{~s}, 3 \mathrm{H}, \mathrm{CH}_{3}\right), 3.5(\mathrm{~s}, 3 \mathrm{H}$, $\left.\mathrm{NCH}_{3}\right), 6.9-7.8(\mathrm{~m}, 16 \mathrm{H}, \mathrm{Ar}-\mathrm{H}), 8.2(\mathrm{~s}, 1 \mathrm{H}, \mathrm{C}-2 \mathrm{H}), 8.5$ (s, 1H, NH, $\mathrm{D}_{2} \mathrm{O}$ exchangeable); Anal. Calcd. for $\mathrm{C}_{32} \mathrm{H}_{24} \mathrm{~N}_{6} \mathrm{O}_{2}$ (524.57): C, 73.28; H, 4.58; N, 16.03\%. Found: C, 73.57; H, 4.24; N, 15.75\%.

5,8,9-Triphenyl-7-(3,4-dichlorophenyl)-3H-pyrrolo[2,3-b]pyrido[4,3-d]pyrimidin-4-one (4d). Yield: 58\%; m.p.: 177-179 ${ }^{\circ} \mathrm{C}$; IR (KBr) v ( $\left.\mathrm{cm}^{-1}\right): 3379(\mathrm{NH}), 1707(\mathrm{C}=\mathrm{O}), 1600(\mathrm{C}=\mathrm{N}) ; \mathrm{MS}(\mathrm{EI}) \mathrm{m} / z: 558(\mathrm{M}+, 43.5 \%$; $\mathrm{M}+2,9.2 \%, \mathrm{M}+4,3.1 \%) ;{ }^{1} \mathrm{H}-\mathrm{NMR}\left(\mathrm{DMSO}-d_{6}\right) \delta(\mathrm{ppm}): 6.8-8.0(\mathrm{~m}, 18 \mathrm{H}, \mathrm{Ar}-\mathrm{H}), 8.25(\mathrm{~s}, 1 \mathrm{H}, \mathrm{C}-2 \mathrm{H})$, 8.46 (s, $1 \mathrm{H}, \mathrm{NH}, \mathrm{D}_{2} \mathrm{O}$ exchangeable); Anal. Calcd. for $\mathrm{C}_{33} \mathrm{H}_{20} \mathrm{Cl}_{2} \mathrm{~N}_{4} \mathrm{O}$ (559.44): C, 70.97; $\mathrm{H}, 3.58 ; \mathrm{Cl}$, 12.54; N, 10.04\%. Found: C, 70.67; H, 3.76; Cl, 12.41; N, 9.79\%.

5,8,9-Triphenyl-7-(4-methoxyphenyl)-3H-pyrrolo[2,3-b]pyrido[4,3-d]pyrimidin-4-one (4e). Yield: 76\%; m.p.: 245-247 ${ }^{\circ} \mathrm{C}$; IR (KBr) v (cm $\left.{ }^{-1}\right): 3406(\mathrm{NH}), 1699(\mathrm{C}=\mathrm{O}), 1586(\mathrm{C}=\mathrm{N}), 1263$ (C-O); MS (EI) m/z: 520 $(\mathrm{M}+, 72.3 \%) ;{ }^{1} \mathrm{H}-\mathrm{NMR}\left(\mathrm{DMSO}-d_{6}\right) \delta(\mathrm{ppm}): 3.64\left(\mathrm{~s}, 3 \mathrm{H}, \mathrm{OCH}_{3}\right), 6.9-8.0(\mathrm{~m}, 19 \mathrm{H}, \mathrm{Ar}-\mathrm{H}), 8.19$ (s, $1 \mathrm{H}, \mathrm{C}-2$ $\mathrm{H}), 8.3$ (s, $1 \mathrm{H}, \mathrm{NH}, \mathrm{D}_{2} \mathrm{O}$ exchangeable); Anal. Calcd. for $\mathrm{C}_{34} \mathrm{H}_{24} \mathrm{~N}_{4} \mathrm{O}_{2}$ (520.58): C, 78.46; $\mathrm{H}, 4.62 ; \mathrm{N}$, 10.77\%. Found: C, 78.71; H, 4.35; N, 10.53\%.

5,8,9-Triphenyl-7-(1,5-dimethyl-3-oxo-2-phenyl-2,3-dihydro-1H-pyrazol-4-yl)-3H-pyrrolo[2,3-b]pyrido[4,3-d] pyrimidin-4-one (4f). Yield: 61\%; m.p.: 195-197 ${ }^{\circ} \mathrm{C}$; IR (KBr) v (cm $\left.{ }^{-1}\right): 3447(\mathrm{NH}), 1682,1714(\mathrm{C}=\mathrm{O})$, $1603(\mathrm{C}=\mathrm{N})$; MS (EI) m/z: $600(\mathrm{M}+, 83.6 \%) ;{ }^{1} \mathrm{H}-\mathrm{NMR}\left(\mathrm{DMSO}-d_{6}\right) \delta(\mathrm{ppm}): 2.71\left(\mathrm{~s}, 3 \mathrm{H}, \mathrm{CH}_{3}\right), 3.7(\mathrm{~s}, 3 \mathrm{H}$, $\left.\mathrm{NCH}_{3}\right)$, 6.7-7.9 (m, 20H, Ar-H), 8.18 (s, 1H, C-2 H), 8.45 (s, 1H, NH, D $\mathrm{O}_{2}$ exchangeable); Anal. Calcd. for $\mathrm{C}_{38} \mathrm{H}_{28} \mathrm{~N}_{6} \mathrm{O}_{2}$ (600.67): C, 76.00; H, 4.67; N, 14.00\%. Found: C, 75.72; H, 4.92; N, 13.85\%.

5-(4-Methoxyphenyl)-9-phenyl-7-(4-methylphenyl)-3H-pyrrolo[2,3-b]pyrido[4,3-d]pyrimidin-4-one (4g). Yield: 73\%; m.p.: 228-230 ${ }^{\circ} \mathrm{C}$; IR (KBr) v ( $\left.\mathrm{cm}^{-1}\right)$ : 3340 (NH), 1691 (C=O), 1617 (C=N), 1229 (C-O); MS (EI) m/z: $458(\mathrm{M}+, 16 \%) ;{ }^{1} \mathrm{H}-\mathrm{NMR}\left(\mathrm{DMSO}-d_{6}\right) \delta(\mathrm{ppm}): 2.5\left(\mathrm{~s}, 3 \mathrm{H}, \mathrm{CH}_{3}\right), 3.67\left(\mathrm{~s}, 3 \mathrm{H}, \mathrm{OCH}_{3}\right), 6.8-7.9(\mathrm{~m}, 14 \mathrm{H}$, Ar-H), 8.1 (s, $1 \mathrm{H}, \mathrm{C}-2 \mathrm{H}), 8.34$ (s, $1 \mathrm{H}, \mathrm{NH}, \mathrm{D}_{2} \mathrm{O}$ exchangeable); Anal. Calcd for $\mathrm{C}_{29} \mathrm{H}_{22} \mathrm{~N}_{4} \mathrm{O}_{2}$ (458.51): C, 75.98; H, 4.80; N, 12.22\%. Found: C, 75.76; H, 4.93; N, 11.85\%.

5,7-Di(4-methoxyphenyl)-9-phenyl-3H-pyrrolo[2,3-b]pyrido[4,3-d]pyrimidin-4-one (4h). Yield: 78\%; m.p.: 223-225 ${ }^{\circ} \mathrm{C}$; IR (KBr) v (cm $\left.{ }^{-1}\right): 3374(\mathrm{NH}), 1703(\mathrm{C}=\mathrm{O}), 1602(\mathrm{C}=\mathrm{N}), 1225(\mathrm{C}-\mathrm{O}) ; \mathrm{MS}(\mathrm{EI}) \mathrm{m} / z: 474(\mathrm{M}+$, 43.6\%); ${ }^{1} \mathrm{H}$ NMR (DMSO-d 6 ) $\delta$ (ppm): 3.45 (s, 3H, $\left.\mathrm{OCH}_{3}\right), 3.6\left(\mathrm{~s}, 3 \mathrm{H}, \mathrm{OCH}_{3}\right), 6.8-7.8(\mathrm{~m}, 14 \mathrm{H}, \mathrm{Ar}-\mathrm{H})$, 8.13 (s, $1 \mathrm{H}, \mathrm{C}-2 \mathrm{H}), 8.4$ (s, $1 \mathrm{H}, \mathrm{NH}, \mathrm{D}_{2} \mathrm{O}$ exchangeable); Anal. Calcd for $\mathrm{C}_{29} \mathrm{H}_{22} \mathrm{~N}_{4} \mathrm{O}_{3}(474.51)$ : C, 73.42; H, 4.64; N, 11.81\%. Found: C, 73.63; H, 4.91; N, 11.59\%.

5-(4-Methoxyphenyl)-9-phenyl-7-(1,5-dimethyl-3-oxo-2-phenyl-2,3-dihydro-1H-pyrazol-4-yl)-3H-pyrrolo[2,3-b] pyrido[4,3-d]pyrimidin-4-one (4i). Yield: 57\%; m.p.: 227-229 ${ }^{\circ} \mathrm{C}$; IR (KBr) $v\left(\mathrm{~cm}^{-1}\right): 3336(\mathrm{NH}), 1706$, 
$1724(\mathrm{C}=\mathrm{O}), 1617$ (C=N), 1238 (C-O); MS (EI) m/z: $554(\mathrm{M}+, 28.4 \%) ;{ }^{1} \mathrm{H}-\mathrm{NMR}\left(\mathrm{DMSO}-d_{6}\right) \delta(\mathrm{ppm}): 2.5$ $\left(\mathrm{s}, 3 \mathrm{H}, \mathrm{CH}_{3}\right), 3.56\left(\mathrm{~s}, 3 \mathrm{H}, \mathrm{OCH}_{3}\right), 3.73\left(\mathrm{~s}, 3 \mathrm{H}, \mathrm{NCH}_{3}\right), 6.8-8.1(\mathrm{~m}, 15 \mathrm{H}, \mathrm{Ar}-\mathrm{H}), 8.2(\mathrm{~s}, 1 \mathrm{H}, \mathrm{C}-2 \mathrm{H}), 8.5$ (s, $1 \mathrm{H}, \mathrm{NH}, \mathrm{D}_{2} \mathrm{O}$ exchangeable); Anal. Calcd. for $\mathrm{C}_{33} \mathrm{H}_{26} \mathrm{~N}_{6} \mathrm{O}_{3}$ (554.60): C, 71.48; H, 4.69; N, $15.16 \%$. Found: $\mathrm{C}, 71.71 ; \mathrm{H}, 4.80 ; \mathrm{N}, 14.80 \%$.

5-(4-Methoxyphenyl)-8,9-diphenyl-7-(3,4-dichlorophenyl)-3H-pyrrolo[2,3-b]pyrido[4,3-d]pyrimidin-4-one (4j). Yield: 52\%; m.p.: $186-188{ }^{\circ} \mathrm{C}$; IR (KBr) $v\left(\mathrm{~cm}^{-1}\right)$ : $3417(\mathrm{NH}), 1718(\mathrm{C}=\mathrm{O}), 1596(\mathrm{C}=\mathrm{N}), 1234(\mathrm{C}-\mathrm{O})$; MS (EI) $m / z: 588\left(\mathrm{M}+, 73.2 \%\right.$; M+2, 29\%; M+4, 6\%); ${ }^{1} \mathrm{H}-\mathrm{NMR}\left(\mathrm{DMSO}-d_{6}\right) \delta(\mathrm{ppm}): 3.51\left(\mathrm{~s}, 3 \mathrm{H}, \mathrm{OCH}_{3}\right)$, 7.0-7.8 (m, 17H, Ar-H), 8.23 (s, 1H, C-2 H), 8.43 (s, 1H, NH, $\mathrm{D}_{2} \mathrm{O}$ exchangeable); Anal. Calcd. for $\mathrm{C}_{34} \mathrm{H}_{22} \mathrm{Cl}_{2} \mathrm{~N}_{4} \mathrm{O}_{2}$ (589.47): C, 69.39; H, 3.74; Cl, 11.90; N, 9.52\%. Found: C, 69.51; H, 3.93; Cl, 11.62; N, 9.81\%.

5,7-Di(4-methoxyphenyl)-8,9-diphenyl-3H-pyrrolo[2,3-b]pyrido[4,3-d]pyrimidin-4-one (4k). Yield: 66\%; m.p.: 256-258 ${ }^{\circ} \mathrm{C}$; IR (KBr) v ( $\left.\mathrm{cm}^{-1}\right): 3475(\mathrm{NH}), 1720(\mathrm{C}=\mathrm{O}), 1592(\mathrm{C}=\mathrm{N}), 1227$ (C-O); MS (EI) m/z: 550 $(\mathrm{M}+, 56 \%) ;{ }^{1} \mathrm{H}$ NMR (DMSO-d 6 ) $\delta(\mathrm{ppm}): 3.5\left(\mathrm{~s}, 3 \mathrm{H}, \mathrm{OCH}_{3}\right), 3.59\left(\mathrm{~s}, 3 \mathrm{H}, \mathrm{OCH}_{3}\right), 7.0-7.9(\mathrm{~m}, 18 \mathrm{H}, \mathrm{Ar}-\mathrm{H})$, 8.2 (s, $1 \mathrm{H}, \mathrm{C}-2 \mathrm{H}), 8.41$ (s, $1 \mathrm{H}, \mathrm{NH}, \mathrm{D}_{2} \mathrm{O}$ exchangeable); Anal. Calcd for $\mathrm{C}_{35} \mathrm{H}_{26} \mathrm{~N}_{4} \mathrm{O}_{3}(550.60)$ : C, 76.36; H, 4.73; N, 10.18. Found: C, 76.65; H, 4.93; N, 9.87\%.

5-(4-Methoxyphenyl)-8,9-diphenyl-7-(1,5-dimethyl-3-oxo-2-phenyl-2,3-dihydro-1H-pyrazol-4-yl)-3H-pyrrolo [2,3-b]pyrido[4,3-d]pyrimidin-4-one (41). Yield: 73\%; m.p.: 204-206 ${ }^{\circ} \mathrm{C}$; IR (KBr) v (cm $\left.{ }^{-1}\right): 3388(\mathrm{NH})$, 1713, 1729 (C=O), 1578 (C=N), 1218 (C-O); MS (EI) m/z: 630 (M+, 21.7\%); ${ }^{1} \mathrm{H}-\mathrm{NMR}\left(\mathrm{DMSO}-d_{6}\right) \delta$ (ppm): $2.4\left(\mathrm{~s}, 3 \mathrm{H}, \mathrm{CH}_{3}\right), 3.62\left(\mathrm{~s}, 3 \mathrm{H}, \mathrm{OCH}_{3}\right), 3.7\left(\mathrm{~s}, 3 \mathrm{H}, \mathrm{NCH}_{3}\right), 6.9-8.0(\mathrm{~m}, 19 \mathrm{H}, \mathrm{Ar}-\mathrm{H}), 8.14(\mathrm{~s}, 1 \mathrm{H}$, $\mathrm{C}-2 \mathrm{H}$ ), 8.33 (s, $1 \mathrm{H}, \mathrm{NH}, \mathrm{D}_{2} \mathrm{O}$ exchangeable); Anal. Calcd for $\mathrm{C}_{39} \mathrm{H}_{30} \mathrm{~N}_{6} \mathrm{O}_{3}$ (630.69): C, 74.29; $\mathrm{H}, 4.76$; N, 13.33\%. Found: C, 73.88; H, 4.89; N, 13.54 .

\subsection{Anti-Inflammatory Activity}

The anti-inflammatory effect of the newly synthesized compounds was evaluated in accordance with the carrageenan-induced paw edema method (Winter et al. [76,77]). Male albino Sprague-Dawley rats (150-175 g) have been used taking into accounts the international principles and local regulations concerning the care and the use of laboratory animals (Olfert et al. 1993) [78]. The animal had free access to a standard commercial diet and water, kept at rooms maintained at about $25{ }^{\circ} \mathrm{C}$. Carrageenan-induced hind paw edema is the standard experimental model of acute inflammation. Carrageenan (Sigma-Aldrich Co., St. Louis, MO, USA) is the phlogistic agent of choice for testing anti-inflammatory drugs as it is not known to be antigenic and is devoid of apparent systemic effects.

Twelve groups of animals each consisting of five rats have been selected. The 1st group was treated with the vehicle and left as control while the 2 nd one was given diclofenac sodium by oral route in a dose of $50 \mathrm{mg} / \mathrm{kg}$ body weight (reference standard) [79] and tested compounds (3b, c, d, $\mathbf{g}$, $\mathbf{h}, \mathbf{I}, \mathbf{j}, \mathbf{k}, \mathbf{1}$ and $\mathbf{4 k}$ ) were orally administered at equimolar dose levels. After $30 \mathrm{~min}$, acute inflammation was induced by sub-plantar injection of $0.1 \mathrm{~mL}$ of $1 \%$ suspension of carrageenan in the right hind paw of all rats. Hind foot-pad thickness was measured with a micrometer caliber before and at 1, 2, 3 and 4 $\mathrm{h}$ after carrageenan injection. Percent inhibition of the tested compounds and the standard drug was calculated in comparison with vehicle control (100\%).

\subsection{Docking and Modelling Methods}

All compounds were built and saved as Mol2 files. The crystal structure of COX-2 enzyme complexed with indomethacin was downloaded from the Protein Data Bank (PDB: 4COX). The protein was loaded into Leadit 2.1.2 [80] and the receptor components were chosen by selection of chain A as a main chain which in complexed with indomethacin. Binding site was defined by choosing naproxen as a reference ligand to which all coordinates were computed. Amino acids within a $8.5 \AA$ radius were selected in the binding site. All chemical ambiguities of residues were left as default. Ligand binding was driven by enthalpy (classic triangle matching). For scoring, all default settings were restored. Intra-ligand clashes were computed by using clash factor $=0.6$. Maximum number of solutions per 
iteration $=200$. Maximum of solution per fragmentation $=200$. The base placement method was used as a docking strategy.

\subsection{Determination of Inflammatory Mediators}

\subsubsection{Determination of Immunoglobulin E (IgE)}

The quantitative determination [81-83] of immunoglobulin E (IgE) concentration in serum was based on a solid phase enzyme-linked immunosorbant assay (ELISA) using a BioCheck kit, Cat. No. BC-1035 according to Ishizaka [81]. Serum, taken from the treated rats after carrageenan injection, was added to the IgE antibody coated microtiter wells and incubated at room temperature for $30 \mathrm{~min}$, then wells were washed, and IgE antibody labeled HRP were added. After incubation at room temperature for $30 \mathrm{~min}$. the wells were washed with water. A solution of TMB reagent was added and incubated for $20 \mathrm{~min}$. at room temperature, resulting in the development of blue color. Then stop solution $(\mathrm{HCl}, 1 \mathrm{~N})$ was added for stopping color development. The color change to yellow and measured spectrophotometrically at $450 \mathrm{~nm}$ using an ELISA reader (ELX808, BIO TEK, Winooski, Vermont, USA). The concentration of IgE for each sample was determined from the standard curve.

\subsubsection{Determination of Interleukin $1 \beta$ (IL-1 $\beta)$}

The serum rat interleukin $1 \beta$ (IL-1 $\beta$ ) concentrations were determined $[54,84]$ using an ELISA kit (WKEA Med Supplies, Changchun, China). Serum was added to IL-1 $\beta$ antibody coated microtiter wells and incubated for $30 \mathrm{~min}$. at $37^{\circ} \mathrm{C}$. Wells were washed. HRP enzyme labeled IL-1 $\beta$ antibody was added to each well and incubated again for $30 \mathrm{~min}$. then, washed. After that substrate was added and incubated for $15 \mathrm{~min}$. at $37^{\circ} \mathrm{C}$. Reaction was stopped and the color change was measured spectrophotometrically at $450 \mathrm{~nm}$ using the BIO TEK ELX808 ELISA reader. The concentration of IL-1 $\beta$ in the samples was determined by comparing the O.D. of the samples to the standard curve.

\subsubsection{Determination of Tumor Necrosis Factor $\alpha$ (TNF- $\alpha$ )}

Serum tumor necrosis factor $\alpha$ (TNF- $\alpha)[60,85]$ concentrations were determined using an ELISA kit (WKEA Med Supplies Cat. No. WH-110). Serum was added to TNF- $\alpha$ antibody coated microtiter wells and incubated for $30 \mathrm{~min}$. at $37^{\circ} \mathrm{C}$. Wells were washed. HRP enzyme labeled TNF- $\alpha$ antibody was added to each well and incubated for $30 \mathrm{~min}$. then, washed. The last steps were similar to those in the determination of interleukin $1 \beta$ (IL-1 $\beta$ ).

\subsubsection{Determination of C Reactive Protein (CRP)}

$C$ reactive protein was determined in serum based upon the reaction [58] between CRP and latex covalently bound antibodies against CRP using a Spectrum CRP TurbiLatex kit, Cat. No. 560001 according to Young) [86]. CRP values were determined photometrically at $540 \mathrm{~nm}$ using a STATLAB SZSL60-Spectrum instrument (Spectrum, Hannover, Germany)

\subsubsection{Determination of Histamine}

Serum histamine levels were determined using an ELISA kit (WKEA Med Supplies, Cat. No. WH-844). Serum was added to histamine antibody coated microtiter wells and incubated for $30 \mathrm{~min}$. at $37^{\circ} \mathrm{C}$. Wells were washed. HRP enzyme labeled histamine antibody was added to each well and incubated for $30 \mathrm{~min}$. then, washed. The last steps were similar to those in the determination of interleukin $1 \beta$ (IL-1 $\beta$ ).

\subsection{Statistical Analysis}

Results have been expressed as the mean $\pm \mathrm{SE}$, and different groups have been compared using one way analysis of variance (ANOVA) followed by Tukey-Kramer test for multiple comparisons. 


\section{Conclusions}

As a part of this initiative we have prepared some fused pyrrolopyridines $\mathbf{3} \mathbf{a}-\mathbf{k}$ and their pyrimidine derivatives $\mathbf{4 a - k}$, and investigated their activities as promising anti-inflammatory structures. The biological results revealed that both fused pyrrolopyridines (3i and 31) show promising activity, and are found to be promising anti-inflammatory agents, coinciding with their docking results. In vitro inflammatory mediators assay have also been examined and revealed good to moderate activities for compounds $\mathbf{3} \mathbf{i}$ and $\mathbf{3 l}$ along with compounds $\mathbf{3} \mathbf{c}$ and $\mathbf{3 j}$. These findings provide guidance for the design and structural modifications of these derivatives for better anti-inflammatory activity, which is important for the development of a new class of anti-inflammatory drugs.

Acknowledgments: We would like to convey and specify like to convey our grateful thanks to Mossad Sayed Mohamed (Professor of Pharmaceutical Organic Chemistry) and the staff members of the Pharm. Org. Chem. Dep. (Faculty of Pharmacy, Helwan University) in appreciation of the great effort in achieving this research with high spirit and positive attitude and greatly appreciate their funding and assistance.

Author Contributions: Samar Said Fatahala and Rania Helmy Abd-El Hameed conceived and designed the experiments; Samar Said Fatahala and Rania Helmy Abd-El Hameed performed the experiments; Samar Said Fatahala and Rania Helmy Abd-El Hameed analyzed the data; Sherifa Hasabelnaby contributed reagents/materials/analysis tools; Ayman Goudah performed the vivo anti-inflammatory assay, Ghada Ibrahim Mahmoud performed the cytokines bioassay. Samar Said Fatahala wrote the paper.

Conflicts of Interest: The authors wish to confirm that there are no known conflicts of interest associated with this publication and confirm that the manuscript has been read and approved by all named authors. Also, the order of authors listed in the manuscript has been approved by all of us, assuring that we have given due consideration to the protection of intellectual property associated with this work and stressing on the fact that we have followed the regulations of our institutions concerning intellectual property. This research did not receive any specific grant from funding agencies in the public, commercial, or not-for-profit sectors.

\section{References}

1. Gasparini, L.; Ongini, E.; Wenk, G. Non-steroidal anti-inflammatory drugs (NSAIDs) in Alzheimer's disease: Old and new mechanisms of action. J. Neurochem. 2004, 91, 521-536. [CrossRef] [PubMed]

2. Nagao, M.; Sato, Y.; Yamauchi, A. Meta-Analysis of Interleukin Polymorphisms and NSAID Usage Indicates Correlations to the Risk of Developing Cancer. Int. J. Genom. Med. 2014, 2, 1-7.

3. Perković, I.; Džolić, Z.R.; Zorc, B. A convenient synthesis of new NSAID esters containing amino acid, urea and amide moieties. Acta Pharm. 2013, 63, 409-418. [CrossRef] [PubMed]

4. Kotake, S.; Yago, T.; Kawamoto, M.; Nanke, Y. Effects of NSAIDs on Differentiation and Function of Human and Murine Osteoclasts-Crucial "Human Osteoclastology". Pharmaceuticals 2010, 3, 1394-1410. [CrossRef] [PubMed]

5. Cho, H.; Walker, A.; Williams, J.; Hasty, K.A. Study of Osteoarthritis Treatment with Anti-Inflammatory Drugs: Cyclooxygenase-2 Inhibitor and Steroids. Biomed. Res. Int. 2015, 2015, 1-10. [CrossRef] [PubMed]

6. Bansal, Y.; Silakari, O. Multifunctional compounds: Smart molecules for multifactorial diseases. Eur. J. Med. Chem. 2014, 76, 31-42. [CrossRef] [PubMed]

7. Ajmone-Cat, M.A.; Bernardo, A.; Greco, A.; Minghetti, L. Non-steroidal anti-inflammatory drugs and brain inflammation: Effects on microglial functions. Pharmaceuticals 2010, 3, 1949-1964. [CrossRef] [PubMed]

8. Fernandes, E.; Costa, D.; Toste, S.A.; Lima, J.L.F.C.; Reis, S. In vitro scavenging activity for reactive oxygen and nitrogen species by nonsteroidal anti-inflammatory indole, pyrrole, and oxazole derivative drugs. Free Radic. Biol. Med. 2004, 37, 1895-1905. [CrossRef] [PubMed]

9. Ushiyama, S.; Yamada, T.; Murakami, Y.; Kumakura, S.I.; Inoue, S.I.; Suzuki, K.; Nakao, A.; Kawara, A.; Kimura, T. Preclinical pharmacology profile of CS-706, a novel cyclooxygenase-2 selective inhibitor, with potent antinociceptive and anti-inflammatory effects. Eur. J. Pharmacol. 2008, 578, 76-86. [CrossRef] [PubMed]

10. Sharma, P.C.; Yadav, S.; Pahwa, R.; Kaushik, D.; Jain, S. Synthesis and evaluation of novel prodrugs of naproxen. Med. Chem. Res. 2011, 20, 648-655. [CrossRef]

11. Praveen Rao, P.N.; Knaus, E.E. Evolution of nonsteroidal anti-inflammatory drugs (NSAIDs): Cyclooxygenase (COX) inhibition and beyond. J. Pharm. Pharm. Sci. 2008, 11, 81-110. 
12. Sánchez-Borges, M.; Caballero-Fonseca, F.; Capriles-Hulett, A.; González-Aveledo, L. Hypersensitivity Reactions to Nonsteroidal Anti-Inflammatory Drugs: An Update. Pharmaceuticals 2010, 3, 10-18. [CrossRef] [PubMed]

13. Joshi, S.D.; More, U.A.; Dixit, S.R.; Korat, H.H.; Aminabhavi, T.M.; Badiger, A.M. Synthesis, characterization, biological activity, and 3D-QSAR studies on some novel class of pyrrole derivatives as antitubercular agents. Med. Chem. Res. 2013, 23, 1123-1147. [CrossRef]

14. Dannhardt, G.; Kiefera, W.; Krämera, G.; Maehrlein, S.; Nowe, U.; Fiebich, B. The pyrrole moiety as a template for COX-1/COX-2 inhibitors. Eur. J. Med. Chem. 2000, 35, 499-510. [CrossRef]

15. Sarg, M.T.; Bayoumi, M.M.K.; Gilil, A.H.; El, S.M.A. Synthesis of Pyrroles and Condensed Pyrroles as Anti-Inflammatory Agents with Multiple Activities and Their Molecular Docking Study. Open J. Med. Chem. 2015, 49-96. [CrossRef]

16. Said, S.A.; Amr, E.G.E.; Sabry, N.M.; Abdalla, M.M. Analgesic, anticonvulsant and anti-inflammatory activities of some synthesized benzodiazipine, triazolopyrimidine and bis-imide derivatives. Eur. J. Med. Chem. 2009, 44, 4787-4792. [CrossRef] [PubMed]

17. Connolly, S.; Aberg, A.; Arvai, A.; Beaton, H.G.; Cheshire, D.R.; Cook, A.R.; Cooper, S.; Cox, D.; Hamley, P.; Mallinder, P.; et al. 2-Aminopyridines as Highly Selective Inducible Nitric Oxide Synthase Inhibitors. Differential Binding Modes Dependent on Nitrogen Substitution. J. Med. Chem. 2004, 47, 3320-3323. [CrossRef] [PubMed]

18. Bukhari, S.N.A.; Jantan, I.; Jasamai, M. Anti-inflammatory trends of 1,3-diphenyl-2-propen-1-one derivatives. Mini Rev. Med. Chem. 2013, 13, 87-94. [CrossRef] [PubMed]

19. Mohamed, M.S.; Fathallah, S.S. Pyrroles and Fused Pyrroles: Synthesis and Therapeutic Activities. Mini Rev. Org. Chem. 2014, 6, 477-507. [CrossRef]

20. Han, W.B.; Zhang, A.H.; Deng, X.Z.; Lei, X.; Tan, R.X. Curindolizine, an Anti-Inflammatory Agent Assembled via Michael Addition of Pyrrole Alkaloids Inside Fungal Cells. Org. Lett. 2016, 18, 1816-1819. [CrossRef] [PubMed]

21. Xu, X.T.; Mou, X.Q.; Xi, Q.M.; Liu, W.T.; Liu, W.F.; Sheng, Z.J.; Zheng, X.; Zhang, K.; Du, Z.Y.; Zhao, S.Q.; et al. Anti-inflammatory activity effect of 2-substituted-1,4,5,6-tetrahydrocyclopenta[b]pyrrole on TPA-induced skin inflammation in mice. Bioorg. Med. Chem. Lett. 2016, 26, 5334-5339. [CrossRef] [PubMed]

22. Yang, S.; Kim, Y.; Jeong, D.; Kim, J.H.; Kim, S.; Son, Y.; Yoo, B.C.; Jeong, E.J.; Kim, T.W.; Lee, I.H.; et al. Pyrrole-Derivative of Chalcone, (E)-3-Phenyl-1-(2-Pyrrolyl)-2-Propenone, Inhibits Inflammatory Responses via Inhibition of Src, Syk, and TAK1 Kinase Activities. Biomol. Ther. 2016, 24, 595-603. [CrossRef] [PubMed]

23. Bhattacharyya, P.; Kishore Kumar, M.; Narasu, L.; Gundla, R.; Samanta, S.; Cuthbertson, C.; Neamati, N. Designing novel MEK1 inhibitors as anticancer agents. Int. J. Life Sci. Pharm. Res. 2016, 6, 23-33.

24. Tintori, C.; Magnani, M.; Schenone, S.; Botta, M. Docking, 3D-QSAR studies and in silico ADME prediction on c-Src tyrosine kinase inhibitors. Eur. J. Med. Chem. 2009, 44, 990-1000. [CrossRef] [PubMed]

25. Danchev, N.; Bijev, A.; Yaneva, D.; Vladimirova, S.; Nikolova, I. Synthesis, acute toxicity, and analgesic activity of new derivatives of pyrrole. Arch. Pharm. (Weinheim) 2006, 339, 670-674. [CrossRef] [PubMed]

26. Chen, T.; Yu, H.; Lai, T.; Chiou, W.; Don, M. Synthesis and anti-inflammatory effect of four rutaecarpine metabolites. J. Chin. Med. 2011, 22, 37-46.

27. Eung, S.L.; Seung, I.K.; Seung, H.L.; Tae, C.J.; Tae, C.M.; Hyeun, W.C.; Jahng, Y. Synthesis and COX inhibitory activities of rutaecarpine derivatives. Bull. Korean Chem. Soc. 2005, 26, 1975-1980.

28. Bocheva, A.; Bijev, A.; Nankov, A. Further evaluation of a series of anti-inflammatory N-pyrrolylcarboxylic acids: Effects on the nociception in rats. Arch. Pharm. (Weinheim) 2006, 339, 141-144. [CrossRef] [PubMed]

29. Lessigiarska, I.; Nankov, A.; Bocheva, A.; Pajeva, I.; Bijev, A. 3D-QSAR and preliminary evaluation of anti-inflammatory activity of series of $N$-pyrrolylcarboxylic acids. Farmaco 2005, 60, 209-218. [CrossRef] [PubMed]

30. Nakao, A.; Ohkawa, N.; Nagasaki, T.; Kagari, T.; Doi, H.; Shimozato, T.; Ushiyama, S.; Aoki, K. Tetrahydropyridine derivatives with inhibitory activity on the production of proinflammatory cytokines: part 1. Bioorg. Med. Chem. Lett. 2009, 19, 4607-4610. [CrossRef] [PubMed]

31. Gallelli, L.; Galasso, O.; Falcone, D.; Southworth, S.; Greco, M.; Ventura, V.; Romualdi, P.; Corigliano, A.; Terracciano, R.; Savino, R.; et al. The effects of nonsteroidal anti-inflammatory drugs on clinical outcomes, synovial fluid cytokine concentration and signal transduction pathways in knee osteoarthritis. A randomized open label trial. Osteoarthr. Cartil. 2013, 21, 1400-1408. [CrossRef] [PubMed] 
32. Page, T.H.; Turner, J.J.O.; Brown, A.C.; Timms, E.M.; Inglis, J.J.; Brennan, F.M.; Foxwell, B.M.J.; Ray, K.P.; Feldmann, M. Nonsteroidal Anti-Inflammatory Drugs Increase TNF Production in Rheumatoid Synovial Membrane Cultures and Whole Blood. J. Immunol. 2010, 185, 3694-3701. [CrossRef] [PubMed]

33. Cole, G.M.; Frautschy, S.A. Mechanisms of action of non-steroidal anti-inflammatory drugs for the prevention of Alzheimer's disease. CNS Neurol. Disord. Drug Targets 2010, 9, 140-148. [CrossRef] [PubMed]

34. Rao, P.P.N.; Kabir, S.N.; Mohamed, T. Nonsteroidal Anti-Inflammatory Drugs (NSAIDs): Progress in Small Molecule Drug Development. Pharmaceuticals 2010, 3, 1530-1549. [CrossRef] [PubMed]

35. Lucetti, D.L.; Lucetti, E.C.; Bandeira, M.; Veras, H.N.; Silva, A.H.; Leal, L.; Lopes, A.A.; Alves, V.C.; Silva, G.S.; Brito, G.; et al. Anti-inflammatory effects and possible mechanism of action of lupeol acetate isolated from Himatanthus drasticus (Mart.) Plumel. J. Inflamm. 2010, 7, 60. [CrossRef] [PubMed]

36. Hossain, M.; Qadri, S.M.; Liu, L. Inhibition of nitric oxide synthesis enhances leukocyte rolling and adhesion in human microvasculature. J. Inflamm. 2012, 9, 28. [CrossRef] [PubMed]

37. Shao, Y.; Cheng, Z.; Li, X.; Chernaya, V.; Wang, H.; Yang, X.-F. Immunosuppressive/anti-inflammatory cytokines directly and indirectly inhibit endothelial dysfunction-A novel mechanism for maintaining vascular function. J. Hematol. Oncol. 2014, 7, 80. [CrossRef] [PubMed]

38. Rashad, A.E.; Mohamed, M.S.; Zaki, M.E.A.; Fatahala, S.S. Synthesis and biological evaluation of some pyrrolo[2,3-d]pyrimidines. Arch. Pharm. (Weinheim) 2006, 339, 664-669. [CrossRef] [PubMed]

39. Mohamed, M.S.; Rashad, A.E.; Zaki, M.E.A.; Fatahala, S.S. Synthesis and antimicrobial screening of some fused heterocyclic pyrroles. Acta Pharm. 2005, 55, 237-249. [PubMed]

40. Mohamed, M.S.; Kamel, R.; Fathallah, S.S. Synthesis of new pyrroles of potential anti-inflammatory activity. Arch. Pharm. (Weinheim) 2011, 344, 830-839. [CrossRef] [PubMed]

41. Mohamed, M.S.; Ali, S.A.; Abdelaziz, D.H.A.; Fathallah, S.S. Synthesis and Evaluation of Novel Pyrroles and Pyrrolopyrimidines as Antihypoglycemic Agents. BioMed Res. Int. 2014, 2014, 249780. [CrossRef] [PubMed]

42. Mohamed, M.S.; Kamel, R.; Abd El-hameed, R.H. Evaluation of the anti-inflammatory activity of some pyrrolo[2,3-d]pyrimidine derivatives. Med. Chem. Res. 2012, 22, 2244-2252. [CrossRef]

43. Zheng, G.Z.; Mao, Y.; Lee, C.H.; Pratt, J.K.; Koenig, J.R.; Perner, R.J.; Cowart, M.D.; Gfesser, G.A.; McGaraughty, S.; Chu, K.L.; et al. Adenosine kinase inhibitors: Polar 7-substitutent of pyridopyrimidine derivatives improving their locomotor selectivity. Bioorg. Med. Chem. Lett. 2003, 13, 3041-3044. [CrossRef]

44. Zheng, G.Z.; Lee, C.H.; Pratt, J.K.; Perner, R.J.; Jiang, M.Q.; Gomtsyan, A.; Matulenko, M.A.; Mao, Y.; Koenig, J.R.; Kim, K.H.; et al. Pyridopyrimidine analogues as novel adenosine kinase inhibitors. Bioorg. Med. Chem. Lett. 2001, 11, 2071-2074. [CrossRef]

45. Rashad, A.E.; Sayed, H.H.; Shamroukh, A.H.; Awad, H.M. Preparation of Some Fused Pyridopyrimidine and Pyridothienotriazine Derivatives for Biological Evaluation. Phosphorus Sulfur Silicon Relat. Elem. 2005, 180, 2767-2777. [CrossRef]

46. Nofal, Z.M.; Fahmy, H.H.; Zarea, E.S.; El-eraky, W. Drug Synthesis Synthesis of New Pyrimidine Derivatives With Evaluation of Their Anti-Inflammatory and Analgesic Activities. Acta Pol. Pharm. 2011, 68, 507-517. [PubMed]

47. Harrak, Y.; Rosell, G.; Daidone, G.; Plescia, S.; Schillaci, D.; Pujol, M.D. Synthesis and biological activity of new anti-inflammatory compounds containing the 1,4-benzodioxine and/or pyrrole system. Bioorg. Med. Chem. 2007, 15, 4876-4890. [CrossRef] [PubMed]

48. Khedr, M.A.; Shehata, T.M.; Mohamed, M.E. Repositioning of 2,4-Dichlorophenoxy acetic acid as a potential anti-inflammatory agent: In Silico and Pharmaceutical Formulation study. Eur. J. Pharm. Sci. 2014, 65, 130-138. [CrossRef] [PubMed]

49. Housby, J.N.; Cahill, C.M.; Chu, B.; Prevelige, R.; Bickford, K.; Stevenson, M.A.; Calderwood, S.K. Non-steroidal anti-inflammatory drugs inhibit the expression of cytokines and induce HSP70 in human monocytes. Cytokine 1999, 11, 347-358. [CrossRef] [PubMed]

50. De Cássia da Silveira e Sá, R.; Andrade, L.; de Sousa, D. A Review on Anti-Inflammatory Activity of Monoterpenes. Molecules 2013, 18, 1227-1254. [CrossRef] [PubMed]

51. Da Silveira E Sá, R.D.C.; Andrade, L.N.; de Oliveira, R.D.R.B.; De Sousa, D.P. A review on anti-inflammatory activity of phenylpropanoids found in essential oils. Molecules 2014, 19, 1459-1480. [CrossRef] [PubMed]

52. Strober, W.; Fuss, I.J. Proinflammatory Cytokines in the Pathogenesis of Inflammatory Bowel Diseases. Gastroenterology 2011, 140, 1756-1767. [CrossRef] [PubMed] 
53. Shaikh, P.Z. Cytokines \& their physiologic and pharmacologic functions in inflammation: A review. Int. J. Pharm. Life Sci. 2011, 2, 1247-1263.

54. Arshad, S.H.; Holgate, S. The role of IgE in allergen-induced inflammation and the potential for intervention with a humanized monoclonal anti-IgE antibody. Clin. Exp. Allergy 2001, 31, 1344-1351. [CrossRef] [PubMed]

55. Zampeli, E.; Tiligada, E. The role of histamine H4 receptor in immune and inflammatory disorders. Br. J. Pharmacol. 2009, 157, 24-33. [CrossRef] [PubMed]

56. Jørgensen, M.; Jørgensen, P.N.; Christoffersen, C.T.; Jensen, K.G.; Balle, T.; Bang-Andersen, B. Discovery of novel $\alpha$-adrenoceptor ligands based on the antipsychotic sertindole suitable for labeling as PET ligands. Bioorg. Med. Chem. 2013, 21, 196-204. [CrossRef] [PubMed]

57. Tang, L.; Jennings, T.A.; Eaton, J.W. Mast cells mediate acute inflammatory responses to implanted biomaterials. Proc. Natl. Acad. Sci. USA 1998, 95, 8841-8846. [CrossRef] [PubMed]

58. Elenkov, I.J. Neurohormonal-cytokine interactions: Implications for inflammation, common human diseases and well-being. Neurochem. Int. 2008, 52, 40-51. [CrossRef] [PubMed]

59. Limban, C.; Missir, A.V.; Fahelelbom, K.M.S.; Al-Tabakha, M.M.; Caproiu, M.T.; Sadek, B. Novel $\mathrm{N}$-phenylcarbamothioylbenzamides with anti-inflammatory activity and prostaglandin $\mathrm{E} 2$ inhibitory properties. J. Drug Des. Dev. Ther. 2013, 7, 883-892.

60. Mastorakos, G.; Karoutsou, E.I.; Mizamtsidi, M. Corticotropin releasing hormone and the immune/inflammatory response. Eur. J. Endocrinol. 2006, 155, S77-S84. [CrossRef]

61. Wojdasiewicz, P.; Poniatowski, Ł.A.; Szukiewicz, D. The role of inflammatory and anti-inflammatory cytokines in the pathogenesis of osteoarthritis. Mediat. Inflamm. 2014, 2014, 561459. [CrossRef] [PubMed]

62. Dinarello, C.A. Interleukin 1 and interleukin 18 as mediators of inflammation and the aging process. Am. J. Clin. Nutr. 2006, 83, 447S-455S. [PubMed]

63. Teeling, J.L.; Cunningham, C.; Newman, T.A.; Perry, V.H. The effect of non-steroidal anti-inflammatory agents on behavioural changes and cytokine production following systemic inflammation: Implications for a role of COX-1. Brain Behav. Immun. 2010, 24, 409-419. [CrossRef] [PubMed]

64. Toledo, T.R.; Dejani, N.N.; Monnazzi, L.G.S.; Kossuga, M.H.; Berlinck, R.G.S.; Sette, L.D.; Medeiros, A.I. Potent anti-inflammatory activity of pyrenocine A isolated from the marine-derived fungus Penicillium paxilli Ma(G)K. Mediat. Inflamm. 2014, 2014, 767061. [CrossRef] [PubMed]

65. Buceta, M.; Domínguez, E.; Castro, M.; Brea, J.; Álvarez, D.; Barcala, J.; Valdés, L.; Álvarez-Calderón, P.; Domínguez, F.; Vidal, B.; et al. A new chemical tool (C0036E08) supports the role of adenosine A2B receptors in mediating human mast cell activation. Biochem. Pharmacol. 2008, 76, 912-921. [CrossRef] [PubMed]

66. Gao, L.-J.; Schwed, J.S.; Weizel, L.; De Jonghe, S.; Stark, H.; Herdewijn, P. Synthesis and evaluation of novel ligands for the histamine $\mathrm{H}$ receptor based on a pyrrolo[2,3-d]pyrimidine scaffold. Bioorg. Med. Chem. Lett. 2013, 23, 132-137. [CrossRef] [PubMed]

67. Cocco, M.T.; Congiu, C.; Lilliu, V.; Onnis, V. Synthesis and in vitro antitumoral activity of new hydrazinopyrimidine-5-carbonitrile derivatives. Bioorg. Med. Chem. 2006, 14, 366-372. [CrossRef] [PubMed]

68. Caram's, B.; Lopez-Armada, M.J.; Cillero-Pastor, B.; Lires-Dean, M.; Vaamonde, C.; Galdo, F.; Blanco, F.J. Differential effects of tumor necrosis factor- $\alpha$ and interleukin-1 $\beta$ on cell death in human articular chondrocytes. Osteoarthr. Cartil. 2008, 16, 715-722. [CrossRef] [PubMed]

69. Ozturk Bilgin, O.; Doguc, D.K.; Altuntas, I.; Sutcu, R.; Delibas, N. Effects of subchronic treatment with ibuprofen and nimesulide on spatial memory and NMDAR subunits expression in aged rats. Iran. J. Pharm. Res. 2013, 12, 877-885. [PubMed]

70. Pouliot, M.; Cleland, L.; Caughey, C.E.; Pouliot, M.; Cleland, L.C.; James, M.J. Regulation of Tumor Necrosis Factor- $\alpha$ and IL-1 $\beta$ Synthesis by Thromboxane A2 in Nonadherent Human Monocytes. J. Immunol. 1997, 351-358.

71. Ren, K.; Torres, R. Role of interleukin-1beta during pain and inflammation. Brain Res. Rev. 2009, 60, 57-64. [CrossRef] [PubMed]

72. Budhiraja, A.; Kadian, K.; Kaur, M.; Aggarwal, V.; Garg, A.; Sapra, S.; Nepali, K.; Suri, O.P.; Dhar, K.L. Synthesis and biological evaluation of naphthalene, furan and pyrrole based chalcones as cytotoxic and antimicrobial agents. Med. Chem. Res. 2011, 21, 2133-2140. [CrossRef] 
73. Sidney, L.E.; Heathman, T.R.J.; Britchford, E.R.; Abed, A.; Rahman, C.V.; Buttery, L.D.K. Investigation of Localized Delivery of Diclofenac Sodium from Poly(D,L-Lactic Acid-co-Glycolic Acid)/Poly(Ethylene Glycol) Scaffolds Using an In Vitro Osteoblast Inflammation Model. Tissue Eng. Part A 2015, 21, 362-373. [CrossRef] [PubMed]

74. Mohamed, M.S.; El-Domany, R.A.; Abd El-Hameed, R.H.; El-hameed, R.H.A.B.D.; Mohamed, M.S.; El-Domany, R.A.; Abd El-Hameed, R.H. Synthesis of certain pyrrole derivatives as antimicrobial agents. Acta Pharm. 2009, 59, 145-158. [CrossRef] [PubMed]

75. Hussein, W.M.; Fatahala, S.S.; Mohamed, Z.M.; McGeary, R.P.; Schenk, G.; Ollis, D.L.; Mohamed, M.S. Synthesis and kinetic testing of tetrahydropyrimidine-2-thione and pyrrole derivatives as inhibitors of the metallo- $\beta$-lactamase from Klebsiella pneumonia and Pseudomonas aeruginosa. Chem. Biol. Drug Des. 2012, 80, 500-515. [CrossRef] [PubMed]

76. Winter, C.A.; Risley, E.A.; Nuss, G.W. Anti-Inflammatory and Antipyretic Activities of Indomethacin, 1-(P-Chlorobenzoyl)-5-Methoxy-2-Methylindole-3-Acetic Acid. J. Pharmacol. Exp. Ther. 1963, 141, 369-376. [PubMed]

77. Kawakita, Y.; Miwa, K.; Seto, M.; Banno, H.; Ohta, Y.; Tamura, T.; Yusa, T.; Miki, H.; Kamiguchi, H.; Ikeda, Y.; et al. Design and synthesis of pyrrolo[3,2-d]pyrimidine HER2/EGFR dual inhibitors: Improvement of the physicochemical and pharmacokinetic profiles for potent in vivo anti-tumor efficacy. Bioorg. Med. Chem. 2012, 20, 6171-6180. [CrossRef] [PubMed]

78. CACC. Guide to the Care and Use of Experimental Animals; CCAC: Ottawa, ON, Canada, 1993; Volume 1.

79. Standing, J.F.; Tibboel, D.; Korpela, R.; Olkkola, K.T. Diclofenac pharmacokinetic meta-analysis and dose recommendations for surgical pain in children aged 1-12 years. Paediatr. Anaesth. 2011, 21, 316-324. [CrossRef] [PubMed]

80. Shi, X.-N.; Li, H.; Yao, H.; Liu, X.; Li, L.; Leung, K.-S.; Kung, H.-F.; Lu, D.; Wong, M.-H.; Lin, M.C.-M. In Silico Identification and In Vitro and In Vivo Validation of Anti-Psychotic Drug Fluspirilene as a Potential CDK2 Inhibitor and a Candidate Anti-Cancer Drug. PLoS ONE 2015, 10, e0132072. [CrossRef] [PubMed]

81. Ishizaka, T. IgE and mechanisms of IgE-Mediated hypersensitivity. Ann. Allergy 1982, 48, 313-319. [PubMed]

82. El Bakali, J.; Muccioli, G.G.; Renault, N.; Pradal, D.; Body-Malapel, M.; Djouina, M.; Hamtiaux, L.; Andrzejak, V.; Desreumaux, P.; Chavatte, P.; et al. 4-Oxo-1,4-dihydropyridines as selective CB2 cannabinoid receptor ligands: structural insights into the design of a novel inverse agonist series. J. Med. Chem. 2010, 53, 7918-7931. [CrossRef] [PubMed]

83. Krasilnikova, A.A.; Shestopalov, M.A.; Brylev, K.A.; Kirilova, I.A.; Khripko, O.P.; Zubareva, K.E.; Khripko, Y.I.; Podorognaya, V.T.; Shestopalova, L.V.; Fedorov, V.E.; et al. Prospects of molybdenum and rhenium octahedral cluster complexes as X-ray contrast agents. J. Inorg. Biochem. 2015, 144, 13-17. [CrossRef] [PubMed]

84. Mojtaba, E.; Somayeh, B.; Payman, A.; Davood, K. Does systemic inflammation and allergen-specific IgE are related to each other in presence asthma. Int. J. Biosci. 2011, 1, 89-94.

85. Hsin, L.; Tian, X.; Webster, E.L.; Coop, A.; Caldwell, T.M.; Jacobson, A.E.; Chrousos, G.P.; Gold, P.W.; Habib, K.E.; Ayala, A.; et al. CRHR 1 Receptor Binding and Lipophilicity of Pyrrolopyrimidines, Potential Nonpeptide Corticotropin-Releasing Hormone Type 1 Receptor Antagonists. Bioorg. Med. Chem. 2002, 10, 175-183. [CrossRef]

86. Donald, S.Y. Effects of Drugs on Clinical Laboratory Tests, 5th ed.; AACC Press: Washington, DC, USA, 2000.

Sample Availability: Samples of the compounds are Available on request. 